\title{
CEO age, shareholder monitoring, and the organic growth of European firms
}

\author{
Giorgio Barba Navaretti - Davide Castellani 1 - \\ Fabio Pieri
}

Accepted: 4 June 2021 / Published online: 4 September 2021

(C) The Author(s) 2021

\begin{abstract}
The question of why some firms grow faster than others is of high theoretical and practical importance. Beyond a wealth of studies based on stochastic models, firm growth has mostly been explained by looking at the structural characteristics of firms, sectors, and countries. The role of managers' characteristics in fostering firms' growth has been explored much less. In this study, we adopt one key characteristic of managers, the age of the chief executive officer (CEO) and examine its relationship with the firm's organic growth. Using data from a large sample of European manufacturing firms, we find that firms managed by young CEOs grow faster in terms of sales and assets, but not in terms of profitability. These results hold with the inclusion of a large vector of firm and CEO
\end{abstract}

\footnotetext{
G. Barba Navaretti

Department of Economics, Management and Quantitative Methods, University of Milan, and Centro Luca d'Agliano, Milan, Italy

e-mail: barba@unimi.it

D. Castellani $(\bowtie)$

Henley Business School, University of Reading, Whiteknights, Reading RG66UD, UK

e-mail: d.castellani@henley.ac.uk

D. Castellani

Department of Economics, University of Perugia, Perugia, Italy

F. Pieri

Department of Economics and Management, University of Trento, Trento, Italy

e-mail: fabio.pieri@unitn.it
}

characteristics, and a battery of robustness checks, including issues related to the time horizon and appointment of CEOs, the educational attainment of younger cohorts of managers, and endogeneity. We hypothesize that young CEOs are incentivized to boost firm growth to signal their talent in the managerial market and to secure a longer stream of future compensation benefits. To the extent that firm growth does not translate into higher profitability, this may create an agency problem, due to the divergence of this corporate strategy from shareholders' targets. In line with this hypothesis, we find that a more concentrated ownership that allows for more effective monitoring moderates the relationship between CEO age and firm growth.

Plain English Summary Firms managed by CEOs younger than 45 grow faster, especially when ownership is not concentrated and does not coincide with management. In a large sample of European manufacturing firms in the period 2009-2014 we find that firms managed by younger CEOs grow faster in terms of sales and assets, but not in terms of profitability. These results suggest that younger CEOs maximize their utility by growing the size of their firms, to signal their talent in the market for managers, and to achieve a higher compensation linked to firm size, instead of the shareholders' target of profit maximization. An effective way to re-align the divergent interests of managers and shareholders is monitoring via more concentrated ownership. Indeed, we find that the relationship between CEO age and firm growth is weaker when ownership is more concentrated. These results bear implications for policy and governance. As for policy, 
given the well-known "gerontocracy" that affects management (and board members) in many European countries, faster turnover in CEOs could foster aggregate growth via higher business dynamism and a more efficient reallocation of market shares. As for governance, we show that the independence of managers from shareholders enhances firm growth.

Keywords Chief Executive Officer (CEO) · CEO age · Organic growth · Agency theory $\cdot$ Concentrated ownership $\cdot$ European manufacturing firms

JEL classification $\mathrm{G} 32 \cdot \mathrm{G} 34 \cdot \mathrm{L} 11 \cdot \mathrm{L} 25 \cdot \mathrm{L} 60$

\section{Introduction}

Why do some firms grow faster than others? This question touches upon a key feature of market economies, which has implications for macroeconomic performance, the evolution of industries, business strategy, and policy-making. From a theoretical perspective, firm growth has been approached from different angles (Geroski, 1999). Starting with stochastic models dating back to the seminal work of Gibrat (1931), much attention has been paid to the question, even in recent times by Hart and Oulton (1996), Bottazzi and Secchi (2006) and Arata (2019), because of the consistent properties of growth rate distributions across countries, industries, and over time (Dosi et al., 2015). Dynamic competitive equilibrium models (Jovanovic, 1982; Ericson \& Pakes, 1995; Cabral \& Mata, 2003; Cooley \& Quadrini, 2004) explain businesses' growth through the structural characteristics of firms, such as newer or younger and smaller sized firms, a higher level of efficiency, investment, and more effective access to financial resources. ${ }^{1}$ Evolutionary models (Dosi et al., 1995; Nelson \& Winter, 1982), which are grounded in the Schumpeterian idea of "creative destruction," have examined the role of innovation in firm dynamics. ${ }^{2}$

\footnotetext{
${ }^{1}$ Inspired by this theoretical framework, a large body of empirical research has investigated the role of these firm characteristics in growth (see Barba Navaretti et al., 2014; Bloningen \& Tomlin, 2001; Das, 1995; Geurts \& Van Biesebroeck, 2016; Hall, 1987; Haltiwanger et al., 2013; Lotti et al., 2009)

${ }^{2}$ Although through a complex relationship, innovation and technological change have been found to determine firm growth in several empirical papers (see Bottazzi et al., 2001; Coad \& Rao, 2008; Harrison et al., 2014)
}

While all these strands of the literature have focused on the role of firms' characteristics in explaining their episodes of size expansion (e.g., Arrighetti, 1994; Capasso et al., 2015; Yang \& Tsou, 2020), the role exerted by managers' targets and characteristics in firm growth has been much less explored, with few exceptions such as the literature on the impact of the characteristics of the firm founders on the growth of new firms (e.g., Colombo \& Grilli, 2005, 2010). This is unfortunate, especially as top executives are the main agents responsible for corporate strategies (Bertrand \& Schoar, 2003; Foss \& Pedersen, 2016; Hambrick \& Mason, 1984).

The principal-agent (P-A) framework, which is traditionally adopted in industrial organization to model the relationship between shareholders and managers' interests within the firm, sheds light on how firm growth may depend on executives' choices. Indeed, while the owners of the firm (principals) are interested in the expected present value of the firm's economic profits, managers (agents) aim at maximizing their utility, which relates more to firm size than to profit (see Baumol, 1959; Marris, 1964; Williamson, 1964). This is because of the positive relationship between managers' compensation and firm size (Jensen, 1986), ${ }^{3}$ which has been empirically confirmed by several studies (see Brunello et al., 2001; Cosh \& Hughes, 1997; Gabaix et al., 2013; Kato, 1997). Based on the P-A framework, managers are expected to push firm size (through growth) beyond the "optimal" size envisaged by shareholders, thus possibly deviating from profit maximization and creating a conflict of interest within the firm.

This study adopts the P-A framework to show how managers' targets and characteristics help explain that part of growth rate variability among firms, which cannot be ascribed to the stochastic, structural, financial, and technological characteristics of the firm. We investigate whether firms' higher propensity to grow may be ascribed to the specific incentives of young chief executive officers (CEOs). We hypothesize that the objective of signaling their managerial talent in the market, and the possibility of receiving a better stream of future compensation benefits, leads younger CEOs to seek higher firm growth in contrast to their older

\footnotetext{
$\overline{{ }^{3} \text { Managers may }}$ be interested in expanding firm size also because of the desire to control more resources and staff (empire building) and to increase their job security via a higher survival rate for larger firms (Donaldson \& Lorsch, 1983)
} 
counterparts. This may well create a divergence of interests with shareholders. Consistent with this framework, we expect the incentives for firm growth given to younger CEOs to be hindered in firms with more concentrated ownership, where shareholder monitoring is more stringent (Chaigneau \& Sahuguet, 2018; Shleifer \& Vishny, 1986).

This study focuses on organic growth, which is usually proxied by the rate of growth of sales or assets. Even if firms achieve their growth through mergers and acquisitions (M\&As), we believe that the interest in organic growth is grounded in three facts. First, the majority of actual growth episodes are due to the internal expansion of firms in terms of capacity and output. Second, M\&As are usually considered "risky" strategies: ${ }^{4}$ these may be preferred by young CEOs simply because of their lower risk aversion due to their youth (Falk et al., 2018). In this study, we include proxies for CEOs' risk tolerance and attempt to estimate the role of young CEOs' incentives and targets in firm growth, "net of" their attitude toward risk. ${ }^{5}$ Third, economic theory has shown that organic growth can generate significant agency problems. ${ }^{6}$

We analyze the role of CEO age in organic growth from a large sample of manufacturing firms from seven European countries (Austria, France, Germany, Hungary, Italy, Spain, and the United Kingdom) in the period 2009-2014. The database we employ results from merging Bureau Van Dijk's (BvD) Amadeus database with the European Firms in a Global Economy (EFIGE) survey. The EFIGE survey has several unique features. First, it is a sample built to represent the manufacturing sectors of the countries covered. In particular, the sampling design follows a stratification by industry, region, and firm size. A relevant implication of this design of

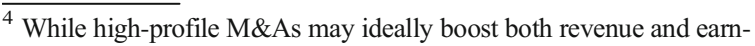
ings per share (Ahuja et al., 2017), the evidence of a positive effect of M\&As on the shareholders' value of the acquiring firm is mixed (see Andrade et al., 2001; Kräkel \& Müller, 2015)

${ }^{5}$ Past studies have attributed younger CEOs' engagement in strategies such as M\&As (Li et al., 2017; Yim, 2013), R\&D investments (Serfling, 2014), and internationalization (Serra et al., 2012) to their superior risk-taking behavior

${ }^{6}$ Indeed, managers may over-invest, to signal that their firm's present value is high, when markets are imperfectly informed about the firm's long-run projects and executives are concerned mainly with short-run evaluations (Bebchuck \& Stole, 1993). Moreover, when the stock market is imperfectly informed about managerial ability, strategies aimed at pumping up current figures may be adopted by the managers, such as devoting efforts to raise current sales volumes at the expense of improving profit margins (Aghion \& Stein, 2008)
}

this study is that we can consider a large number of mostly privately held firms (only about $2 \%$ of firms in the sample are listed) including over $90 \%$ small- and medium-sized enterprises (SMEs; with less than $€ 50$ million turnover). This allows us to highlight that agency problems in the relationship between shareholders and managers are not an exclusive feature of large and widely held firms. Indeed, while a firm where one person wields both the ownership and management roles can be considered the base case of zero-agency costs (Jensen \& Meckling, 1976), the initial separation between ownership and control takes place precisely when a firm is small (Danielson \& Scott, 2007). Second, data from EFIGE are fully comparable across countries, since they are derived from responses to the same questionnaire, administered over the same time span (January to May 2010). Third, EFIGE includes a wide range of questions that allow us to control for a rich set of important firm and CEO characteristics, which is key to limiting omitted variable bias issues. Our final sample includes about 7200 manufacturing firms, across twenty-four 2-digit industries.

Our econometric analysis shows three key results. First, when controlled for industry-country unobserved heterogeneity and a relevant set of firm and CEO characteristics, firms managed by CEOs younger than 45 grow faster (over the period 2009-2014) in terms of both sales and total assets than those managed by older CEOs at the median $\left(50^{\text {th }}\right.$ percentile $)$ of the conditional growth rate distribution. Through quantile regressions, we also show that the effect is asymmetric along the distribution of growth rates: firms managed by younger CEOs do grow more than their counterparts managed by older CEOs, and this difference is stronger in the highest $\left(75^{\text {th }}\right.$ and $\left.90^{\text {th }}\right)$ conditional percentiles. This result is consistent across all the countries considered. Second, our results show no significant statistical relationship between the growth in operating profits and CEO age. We consider this second result as evidence of a potential divergence of interests between CEOs and shareholders. Third, and consistently with agency theory, we find that in firms characterized by more effective monitoring of managers' decisions (proxied by more concentrated ownership), the relationship between CEO age and firm organic growth is much weaker.

As EFIGE is a cross-sectional survey, we cannot employ an identification strategy based on changes in the longitudinal dimension of the CEO age variable. Nonetheless, we control for different time horizons over 
which growth rates are calculated, to minimize the risk of biased results due to the (unobserved) turnover of CEOs. Moreover, we take the potential endogeneity issue stemming from CEO selection based on firms' growth trajectories and other characteristics into account by employing a propensity score matched (PSM) sample analysis. Finally, we show that our results are consistent even with the inclusion of a proxy for the level of education of managers. We conduct several robustness checks on the linearity of the CEO age effect, the role of CEO tenure, and the existence of country specificities in the relationship between CEO age and firm organic growth. The main results are robust to all these checks.

Our study contributes to modern literature on industrial dynamics, by offering some interesting insights on the role played by the age of managers in firm growth. While the growth effect of firm characteristics such as age, size, efficiency, innovative activities, and demand factors have been intensively examined (El Shoubaki et al., 2020; Esteve-Pérez et al., 2021; Foster et al., 2016; Heshmati, 2001), less evidence has been provided regarding the role played by the characteristics of the individuals who lead the firm.

This study also relates to the literature that inquires about the role of managerial characteristics in firms' strategies (see Cronqvist et al., 2012; Faccio et al., 2016; Malmendier \& Tate, 2005, 2008). From this perspective, our study is related to Li et al.'s (2017) work which provided evidence that career concerns explain why younger CEOs take investment decisions that boost firm growth. It is also related to Belenzon et al.'s (2019) work which examines the relationship between firm growth and CEO age in a sample of European companies from BvD's Amadeus. However, two novel perspectives are contributed by this work. First, unlike Li et al. (2017) who rely on a sample of only large US firms (with an average plant size of about 300 employees), our analysis covers a set of diverse EU countries and is based on a sample that includes over 90\% SMEs (with 87 employees per firm on average, and a median size of 26 employees). This is key to highlighting that agency problems are also at work in firms of smaller size. Second, while Belenzon et al. (2019) only focus on owner-managed firms to "[...] eliminate the potential agency problems [...], which could affect managerial actions and hence firm growth $[\ldots]$ " (p. 924), we focus precisely on this agency problem by comparing the relationship between CEO age and firm growth in firms with different degrees of ownership concentration. Indeed, our empirical design delivers enough variability in governance structures, which allows us to test for the role of concentrated ownership as a monitoring device that can align CEOs' strategies with shareholders' interests.

The rest of this paper is structured as follows. Section 2 draws the theoretical underpinnings of the relationship between CEO age and firm growth. Section 3 describes the data. Section 4 presents the econometric results, and the robustness checks and Section 5 concludes.

\section{Literature review and hypotheses development}

\subsection{CEO age, risk aversion, and corporate strategies}

Younger CEOs may be more risk-tolerant, thus pursuing riskier and incidentally size-enhancing strategies (like M\&As, R\&D investments, and internationalization). In a representative sample of 80,000 individuals from 76 countries, Falk et al. (2018) have demonstrated a positive relationship between risk aversion and individual age. Existing empirical studies largely support a negative relationship between CEO age and managerial risk-taking. Serfling (2014) finds a negative relationship between CEO age and firms' risky strategies, i.e., R\&D investments, un-diversified acquisitions and operations, and higher operating leverage. Elia et al. (2021) confirm that older CEOs are less likely to engage in cross-border M\&As in unrelated industries, although they find an inverted-U relationship, suggesting that inexperience and limited track record of the youngest CEOs make their positions more uncertain and volatile, thus reducing their propensity towards riskier strategies. Yim (2013) empirically confirms that firms managed by younger CEOs demonstrate a higher probability of pursuing M\&As in the period 1992-2007. Li et al. (2017) find that firms managed by younger CEOs are more likely to significantly invest and divest than firms managed by older CEOs.

However, not all episodes of firm growth are the result of risky strategies: for example, managers may devote effort toward organic growth via aggressive pricing strategies that can boost sales volumes and increase market share, possibly at the expense of profitability (Aghion \& Stein, 2008). 
This then begs the question: what factors, other than their inherently lower risk aversion, would motivate young CEOs to boost their firms' organic growth?

\subsection{Signaling, compensation, and career concerns}

First, there may be a managerial signaling factor (Prendergast \& Stole, 1996). A young CEO may prefer rapid expansion of firm size - rather than to achieve the optimal firm size (for shareholders) — to signal their talent or capabilities to the market for managers. Conversely, older CEOs may be more reluctant to change their investment behavior frequently because this may be a sign of previous unsuccessful decisions (conservatism). Second, a compensation incentive factor may also be at work. To the extent that firm size is a primary determinant of the CEO's remuneration (see Brunello et al., 2001; Cosh \& Hughes, 1997; Gabaix et al., 2013; Kato, 1997) and given that an optimal contracting scheme cannot be signed, ${ }^{7}$ CEOs may be incentivized to pursue size expansion early on in their careers to access longer streams of future compensation benefits (Yim, 2013). Third, the upper echelons theory (Hambrick \& Mason, 1984) would also predict that older CEOs attach more value to career and financial security and exhibit a greater commitment to the status quo of the firm. Indeed, older CEOs may see their time of retirement as a moment of imminent assessment of their jobs and roles in the organization and may prefer legacy conservation and wealth preservation.

While the factors discussed above predict a negative relationship between CEO age and firm growth, career concerns may work in the opposite direction. Indeed, younger CEOs may face a higher probability of being fired due to a yet unestablished or fledgling reputation ${ }^{8}$ and thus suffer greater market scrutiny (Holmstrom, 1999; Scharfstein \& Stein, 1990). If that is the case, young CEOs may pursue less size-enhancing investments with respect to their older counterparts, especially if these are also risky strategies (Hong et al., 2000). However, career concerns should be less relevant in

\footnotetext{
${ }^{7}$ If an optimal contracting scheme could be signed between shareholders and managers, a higher compensation in larger firms may simply remunerate the higher effort and abilities needed to manage those firms with respect to their smaller counterparts

${ }^{8}$ Again, this would be the case of a not-perfectly-informed market for managers, that is learning about the ability of the manager, based on previous performance. Conversely, in a perfectly informed market for managers, the compensation setting would not create incentives for CEOs to deviate from the optimal (for the shareholder) growth rate
}

the context of the present work, given that organic growth may well be pursued via non-risky strategies, such as reduction in the price-cost margin. A firm may devote efforts toward growth and the expansion of its market share by lowering the price-cost margin, and this may create a divergence in interests between firm growth (managers) and profit maximization (shareholders).

Among a variety of solutions proposed to reconcile this divergence, monitoring of executives by more concentrated ownership is certainly one of the most common, due to several reasons (Chaigneau \& Sahuguet, 2018; Shleifer \& Vishny, 1986; Shleifer \& Vishny, 1997). First, large blockholder owners have the incentive, given the magnitude of their ownership stake, to collect information on executives' actions. Second, they have high voting power to put pressure on the managers and possibly threaten removal (e.g., via a takeover). Third, when large shareholders own more than half of the firm's equity shares, they have full control over the firm and its management.

The role of ownership concentration seems relevant in the context of our empirical analysis of European firms. The evidence suggests that in continental Europe, high reliance is placed on large investors and their monitoring effectiveness (with respect to alternative mechanisms, such as superior legal protection of investors or incentive contracts) in aligning the interests of the owners and their managers (La Porta et al., 1998). The empirical evidence has shown that ownership concentration can be an effective tool in aligning shareholders' interests with executives' utility. ${ }^{9}$

To the extent that the relationship between CEO age and firm organic growth is due to divergent interests between shareholders (more interested in profit growth) and CEOs (more interested in firm growth), one could expect this relation to be weaker when agency problems are reduced via effective monitoring, which may be achieved through more concentrated ownership. The discussion above leads us to hypothesize that:

\footnotetext{
${ }^{9}$ Thomsen and Pedersen (2000) find a positive effect of ownership concentration on the market-to-book value of equity and profitability in a sample of about 450 very large European companies observed during the first half of the 1990s. Bruton et al. (2009) have found support for concentrated ownership improving initial public offering (IPO) performance over the period 1996-2002 in a sample of both British and French companies. Evidence has also been provided on the role that concentrated ownership plays in lowering the probability of valuereducing acquisitions (see Amihud \& Lev, 1981; Denis et al., 1998)
} 
H1. Firms with younger CEOs show higher rates of organic growth, even conditional on risk-taking.

H2. The negative relation between CEO age and firm organic growth is weaker in firms with more concentrated ownership.

\section{Data and descriptive analysis}

In this study, we rely on a unique source of data which results from merging Bureau Van Dijk (BvD)'s Amadeus with the EU-EFIGE/Bruegel-UniCredit dataset (EFIGE). Amadeus is a well-known and widely used source of economic and financial information on European companies. For the purposes of this study, we were able to gather data on the period from 2001 to 2014. EFIGE is the result of a survey administered within the project European Firms in a Global Economy: internal policies for external competitiveness, which was supported by the Directorate General Research of the European Commission through its Seventh Framework Programme ${ }^{10}$. In a first for Europe, EFIGE combines measures of firms' international activities (e.g., exports, imports) with quantitative and qualitative information on about 150 items ranging from $R \& D$ and innovation, labor organization, financing, and organizational activities. Data consist of a representative sample (at the country level for the manufacturing industry) of almost 15,000 surveyed firms (above ten employees) in seven European economies (Germany, France, Italy, Spain, United Kingdom, Austria, and Hungary). Data were collected in 2010, and most questions refer to the year 2008. In some cases, respondents (i.e., individuals who were occupying leading positions in their firms) were asked about the activities of their firms during the years 2007-2009. Considering that the information on the age of CEOs is available for the year 2009, we use the information available in Amadeus, to calculate our dependent variable as the growth rate per unit of time (following Evans, 1987; Variyam \& Kraybill, 1992; Moschella et al., 2019):

$\overline{g r}_{i, 2009-2014}=\frac{\ln \left(S I Z E_{i, 2014}\right)-\ln \left(S I Z E_{i, 2008}\right)}{6}$

\footnotetext{
${ }^{10}$ More information on the EFIGE project and survey are available at http://bruegel.org/publications/datasets/efige/ and in Altomonte et al. (2012)
}

where $S I Z E_{i, t}$ is equal to the operating revenue (sales) of firm $i$ at the end of year $t .{ }^{11}$ This approach is better suited to analyze medium-run growth profiles of firms, which are more likely to result from CEOs' strategies and less affected by noise and measurement errors, which can be severe in the case of yearly growth rates (Pieri, 2018). However, growth rates over longer periods, such as our 6-year period, may be more prone to the fallacy of not capturing a change (turnover) in CEO, which cannot be directly controlled in the data. To partially cope with this issue, we will replicate our analysis over shorter periods of time (see Section A.3.1 in the Online Appendix for a discussion on this issue). It is worth mentioning that the information on sales growth derives from unconsolidated accounts, which excludes growth through M\&As, hence accurately reflecting organic growth. Since data on firm turnover is not available for all firms for the relevant years, our initial sample is effectively reduced to about 7200 firms. ${ }^{12}$ About $93 \%$ of our sample firms have turnover values of less than $€ 50$ million and are thus SMEs.

The EFIGE survey provides information on the age of the CEO as a categorical variable with seven items (<25 years old; $25-34 ; 35-44 ; 45-54 ; 55-64 ; 65-74$; $>=75$ ). The frequency distribution of the sample firms across these CEO age bins is shown in Fig. 1.

The histogram shows that the modal value of CEO age corresponds to the category $45-54$ years. While it is impossible to have a precise figure for the median and mean age of the CEOs in our sample, an inspection of Fig. 1 suggests that it could be slightly above 50, which is in line with the evidence provided by other academic studies and scientific reports ${ }^{13}$. For example, Faccio

\footnotetext{
${ }^{11}$ We re-run the main empirical model by using the value of total assets at the end of the year as a proxy for firm size and the main results are confirmed. We cross-refer the reader to Table 6

${ }^{12}$ The reader is cross-referred to Tables A.1 and A.2 in the Online Appendix. Admittedly, while a change in the sample composition takes place with respect to the countries considered (by moving from the Amadeus/EFIGE sample, i.e., the starting point, to the one used in Table 1 and col.1 of Table 3), it seems not to hold with respect to industry composition and CEO age composition, being the last characteristic that is most relevant to our analysis.

${ }^{13}$ The average age of the CEOs of $S \& P 500$ companies in 2016 was 58 , but the age heterogeneity in the sample was staggering. While the CEOs of some successful companies, such as Facebook, Electronic Arts and Yahoo was about 40 years or younger, others were well into their 70s, such as the CEOs of M\&T Bank, Ralph Lauren Corp., and FedEx Corp. (Schloetzer et al., 2017; World Economic Forum, 2016). This heterogeneity is not just common among large enterprises but is also a feature of smaller, often unlisted companies that are active across different industries and countries.
} 
et al. (2016) report a mean (median) age of 50.3 (51) for the CEOs of the firms included in their analysis, while in the sample of firms used by Li et al. (2017) and Belenzon et al. (2019) the mean age of CEOs is at 53.6 and 50.6, respectively.

To clearly separate young and old CEOs, and in line with previous studies on the role of CEOs in firms' strategies, we group the seven categories into two macro-categories: CEOs younger than 45 versus the rest. ${ }^{14}$ While about $76 \%$ of our sample firms are managed by CEOs who are 45 or older, the share of CEOs younger than 45 is not negligible (24\%). ${ }^{15}$

The EFIGE survey allows us to control for several firm and CEO characteristics that could confound the relationship between firm growth and CEO age, thus limiting the omitted variable bias issue. In particular, we have information on firm age (based on the year of establishment), which is typically associated with firm growth (Barba Navaretti et al., 2014). We also control for the propensity to innovate (Geroski, 1999) and the degree of internationalization (Serra et al., 2012), which are typically associated with risk-taking, hence could result in higher firm growth. Moreover, we can account for firms that have undergone any form of quality certification and widened their product range, as strategies for building a customer base (Foster et al., 2016). We also control for several proxies of economic and financial characteristics of firms, such as firm size (Hall, 1987; Lotti et al., 2009) profitability (Coad, 2007), debt to asset ratio and past sales growth rate, all calculated from BvD's Amadeus over the period 2001-2008. As for CEOs, we can control for several characteristics associated with their risk-tolerance, including their gender, international experience, and over-confidence. Young CEOs may be more overconfident than their older counterparts (Citci \& Inci, 2016): over-confident CEOs systematically overestimate their ability to create value and, in the case of abundant internal financing, tend to overinvest (Malmendier \& Tate, 2005, 2008). This may affect firm growth, especially at the early

\footnotetext{
$\overline{{ }^{14} \text { However, we }}$ will relax this assumption to allow for a different threshold of CEO age on firm growth as a robustness check. The reader is cross-referred to section A.3.4 and Table A.9 in the Online Appendix

${ }^{15}$ Significant cross-country heterogeneity is found in the distribution of CEOs by age class. We cross-refer the reader to Section A.3.8, Table A.2 and Table A.13 in the Online Appendix, for more of this evidence
}

stages of startups (Szerb \& Vörös, 2019). ${ }^{16}$ A detailed description of the variables used in the empirical model is contained in Table 2 .

Table 1 provides some summary statistics on the sales growth rates in the period 2009-2014. ${ }^{17}$

Bearing in mind that the 2009-2014 period embraces the years of the Great Recession, which impacted Europe heavily, it is not surprising that the sales growth rates per unit of time at both the 50th percentile and the mean of the distribution have been negative (approximately -0.008 and $-0.031 \log$ changes, respectively, as shown in Panel A). In line with our expectations, the median firm managed by a CEO younger than 45 has experienced a negative growth rate but lower (in absolute value) than the median firm managed by an older CEO. To account for possible differences across industries and countries, we also computed the growth rates per unit of time adjusted by industry (2-digit NACE rev.2), country, and year: ${ }^{18}$ these are shown in Panel B of Table 1. The growth rate of the group of firms managed by CEOs younger than 45 is around 0.7 points higher than the growth rate of the group of firms managed by CEOs who are 45 or older, at the 50th percentile of the growth rate distribution. This difference is statistically significant as shown in the bottom panel of Table 1 (as per the $p$ value associated with the Wilcoxon; Mann-Whitney test). Moreover, the lower (in absolute value) skewness of the growth rate

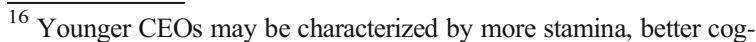
nitive abilities, such as efficiency and effectiveness of information processing (i.e., speed, reasoning, and memory), which may well be related to both the ability of the CEO to capture growth opportunities and (inversely) their age (Child, 1974). Due to the nature of our data, we are not able to control for some age-related CEO characteristics, such as stamina and cognitive abilities. Nonetheless, we submit that if the association between CEO age and firm growth was driven by these peculiar individual characteristics of younger CEOs - instead of a specific set of incentives - there would be no obvious reason as to why it should be moderated by the effectiveness of large shareholders' monitoring

${ }^{17}$ We acknowledge a significant drop in the number of firms with respect to those in Figure 1. This is due to the lower number of firms for which information on operating revenues (sales) are available in the BvD's Amadeus-EFIGE database with respect to the starting-point sample. As anticipated in footnote 12, changes in sample composition are mainly related to countries' coverage, and not to industries coverage, nor to CEO age categories composition. See Tables A.1 and A.2 in the Online Appendix.

${ }^{18}$ Adjusting growth rates by industry, country and year is a standard practice also employed to remove common trends, such as inflation and business cycle effects, which may vary across countries and industries. In practice, we subtract the average value of sales by country, industry and year from firm sales and then compute growth rates on these adjusted values.
} 
Fig. 1 Histogram on the percentage of firms by CEO age category. This histogram shows on the $\mathrm{x}$-axis, the seven categories of age of the CEO, as they are available in the EFIGE survey. Overall, 13533 manufacturing firms included in the AmadeusEFIGE sample have information on the age category of their CEO. The $y$-axis shows the percentages of firms corresponding to each CEO age class

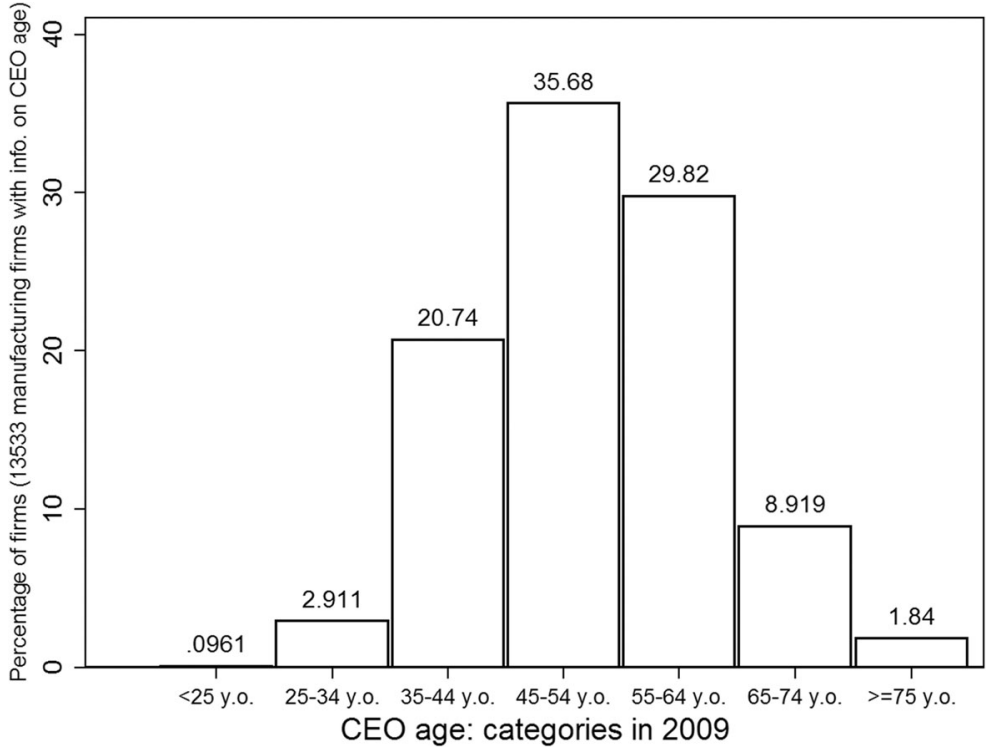

distribution for the firms managed by CEOs younger than 45 points to fewer episodes of heavy size contraction for this group of firms in the period 2009-2014. Figure 2 confirms these results.

The distribution of sales growth rates for the firms managed by younger CEOs (grey line) shows not only a higher median but also a higher number of episodes of positive and fast growth and fewer episodes of heavy and negative growth (contraction) than the distribution of growth rates of firms managed by CEOs who are 45 or older. It is relevant to underline that the distribution of growth rates is not normal, while better approximated by a Laplace (symmetric exponential) distribution (Bottazzi et al., 2001; Bottazzi \& Secchi, 2006). The characteristic tent-shape of this distribution points to the existence of "fat tails", i.e., the higher incidence of episodes of fast growth and heavy contraction with respect to what a Gaussian (normal) distribution would predict. ${ }^{19}$ The presence of fat tails justifies two choices made in the econometric analysis. First, the adoption of a least absolute deviations (LAD) estimator instead of the more common ordinary least squares (OLS) to get insights into the central tendency growth rate of firms managed by CEOs of different ages. Indeed, the first estimator is more robust in the case of a non-Gaussian distribution of the dependent variable (Wooldridge,

\footnotetext{
${ }^{19}$ The reader is cross-referred to Section A.1 of the Online Appendix for a graphical analysis of the distribution of growth rates of the European manufacturing firms in the sample
} 


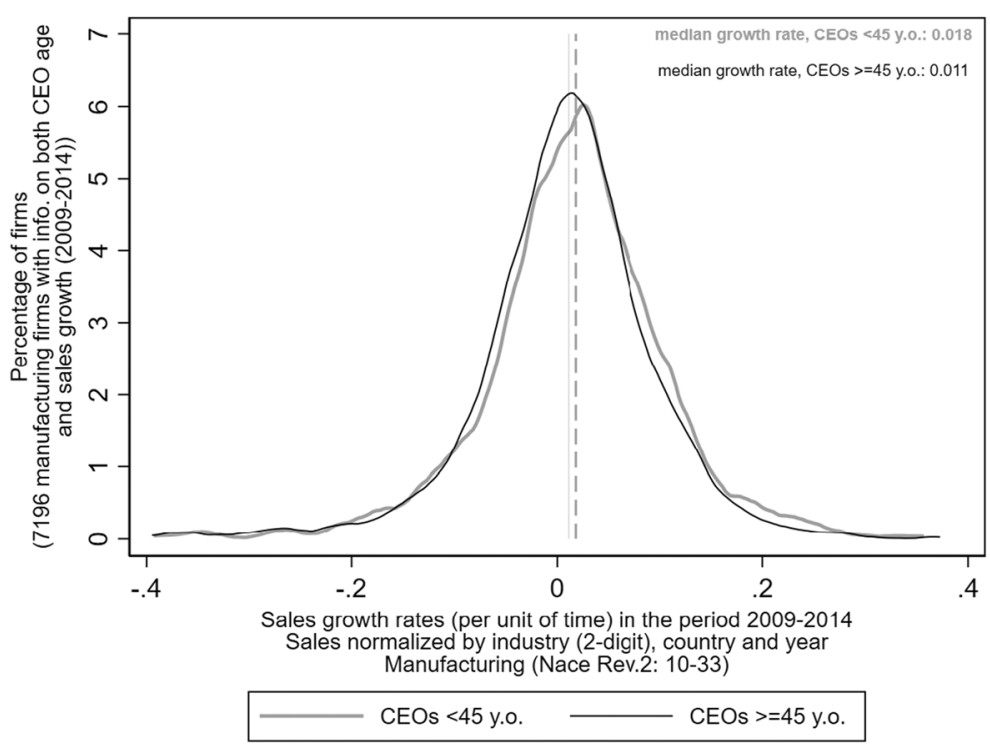

Fig. 2 Distributions of sales growth rates (per unit of time) in the period 2009-2014 by CEO age category. This figure plots the distributions of sales growth rates (per unit of time) calculated over the period 2009-2014 by CEO age category for those firms in the Amadeus-EFIGE database with information on both CEO age and growth in the period 2009-2014. The $\mathrm{x}$-axis indicates the sales

2010), like that of sales growth rates. Second, the attention paid to differences in growth between firms managed by CEOs of different ages, which may especially be in the tails of the distribution. To uncover them, we will use a generalization of the LAD estimator, i.e., quantile regressions.

Table 2 shows some descriptive statistics regarding firms' and CEOs' characteristics of the European manufacturing firms contained in the Amadeus-EFIGE database.

Firms managed by younger and older CEOs are different in several dimensions, and the last column of Table 2 confirms that these differences are usually statistically significant. The median firm in our sample, managed by a young CEO, is smaller, younger, more profitable, and more indebted ${ }^{20}$ than its counterpart that is run by an older CEO and more likely to have introduced process innovations, while being less internationalized (in terms of the number of markets served via exports). Moreover, a higher share of females

\footnotetext{
${ }^{20}$ We thank a reviewer for bringing to our attention corporate finance literature, which generally assumes that in following the "pecking order" hypothesis, firms always prefer debt to equity. Hence, if young CEOs obtain debt financing, this is a signal that credit suppliers have confidence in the firm and that its managers are not forced to seek equity funding
}

growth rates (only values within the interval from -0.4 to 0.4 have been reported in the plot to make it more readable), while the yaxis reports the percentage of firms. Firms' sales have been normalized by industry (2-digit), country and year averages to remove common trends, such as inflation and business cycles effects

is observed among younger CEOs, who are also found to be more overconfident. Finally, firms managed by young CEOs grew more than their counterparts did in the period 2001-2008. With the two groups of firms being different in several dimensions, we will conduct a multivariate analysis, controlling for firms and CEOs' characteristics which may well be correlated with both CEO age and firm organic growth.

\section{Econometric analysis}

\subsection{Baseline estimates}

Our baseline empirical model is a cross-sectional regression model of firm growth rates per unit of time calculated over a 6-year period as a function of CEO and firm characteristics at the beginning of the period. It may be written as:

$$
\begin{aligned}
g r_{i, 2009-2014}= & \alpha_{\theta}+\beta_{\theta} C E O(<45 y . o .)_{i, 2009} \\
& +\gamma_{1{ }_{\theta}^{\prime}} Z_{i, 2001-2008}+\gamma_{2 \theta}^{\prime} W_{i, 2008} \\
& +\mu_{\theta j} \cdot \tau_{\theta c}+\varepsilon_{\theta i, 2009-2014}
\end{aligned}
$$




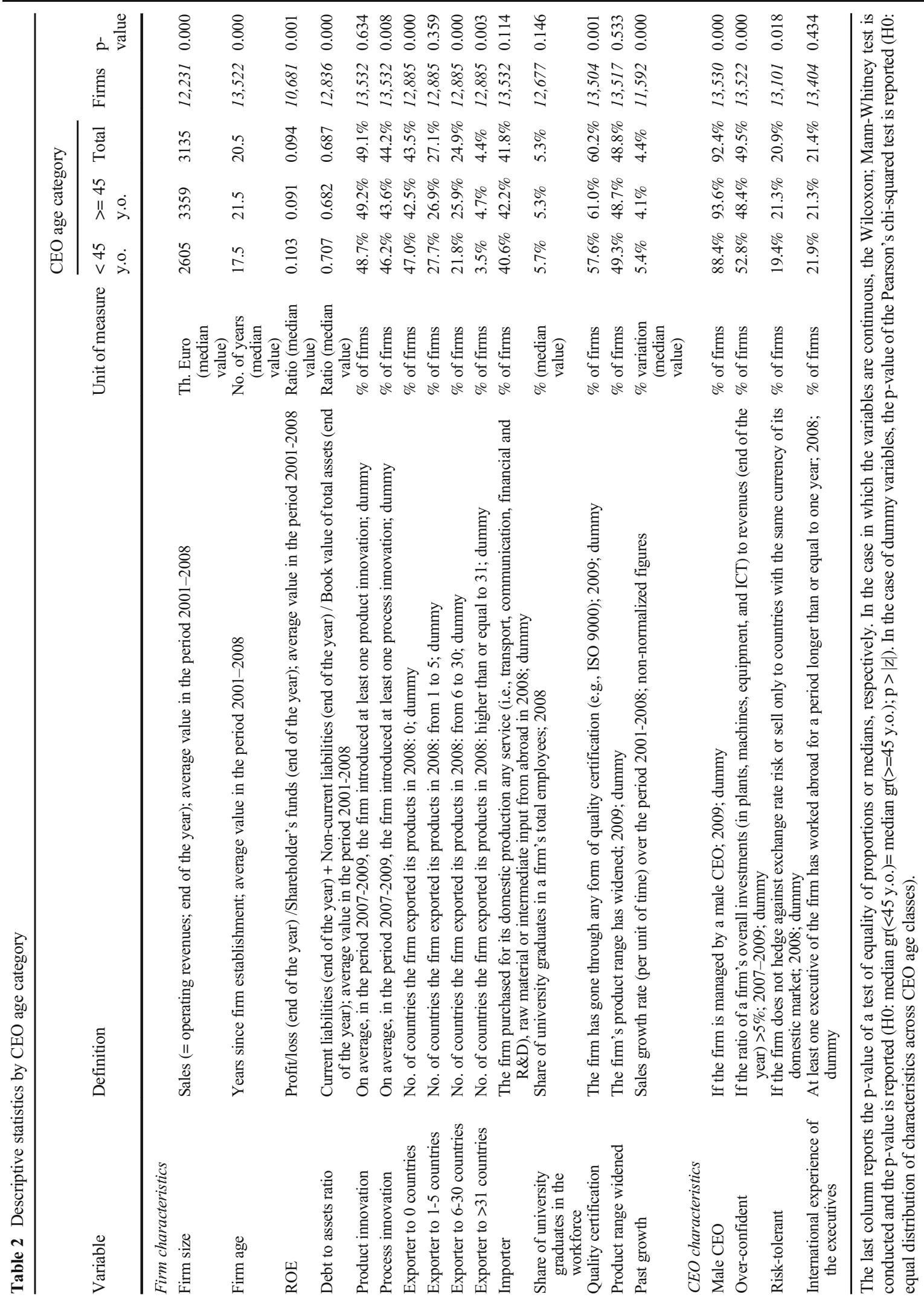


$\overline{g r}_{i, 2009-2014}$ is the growth rate per unit of time of the firm $i$ in the period 2009-2014, and CEO $(<45 \text { y.o. })_{i}$, 2009 is a dummy variable taking value one if the CEO is younger than 45 and zero otherwise. The vector $\bar{Z}_{i, 2001-2008}$ contains proxies (calculated as averages over the period 2001-2008) for relevant characteristics of firm $i$, which may be related to both CEO age and firm growth, i.e., firm size and firm age, firm profitability, and debt to assets ratio. ${ }^{21}$ The vector $W_{i, 2008}$ contains proxies of both firm and $\mathrm{CEO} /$ executive characteristics obtained from the EFIGE survey, which mostly refer to 2008. Variables included in the $\bar{Z}_{i, 2001-2008}$ and $W_{i, 2008}$ vectors have been described in Section 3. In all specifications, we include a vector of country-industry fixed effects (indicated by the subscripts $c$ and $j$, respectively), where manufacturing industries are defined at the 2digit NACE rev.2 level of classification ${ }^{22}$ to control for systematic differences in firm growth and CEO age across countries and industries. We also report the heteroskedastic robust standard errors (as suggested by Machado et al., 2011) in parentheses. ${ }^{23}$ It is worth mentioning that our analysis is conditional on firm survival until the end of the period over which the growth rate is calculated, which is either 2014 or earlier because in several robustness checks, the growth rate per unit of time is calculated over shorter time horizons (see Section A.3.1 and Table A.3 in the Online Appendix). This is in line with several studies in the literature on firm growth, such as Coad (2007), Coad and Rao (2008), Barba Navaretti et al. (2014), Bianchini et al. (2017), Pieri (2018), and Moschella et al. (2019).

As described in Section 3.1, we employ the quantile regression estimator (Koenker \& Basset, 1978), which is the vector of parameters $\delta$ that solves the following operation: ${ }^{24}$

$$
\min _{\delta} \frac{1}{n}\left\{\sum_{i: \overline{g r}_{i, 2009-2014} \geq \delta^{\prime} X_{i}} \theta\left|\overline{g r}_{i, 2009-2014}-\delta^{\prime} X_{i}\right|+\sum_{i: \overline{g r}_{i, 2009-2014}<\delta^{\prime} X_{i}}(1-\theta)\left|\overline{g r}_{i, 2009-2014}-\delta^{\prime} X_{i}\right|\right\},
$$

where, for notational simplicity, we denote the vector of the "right-hand-side" variables in Eq. 2 as $X_{i}$ and the respective vector of parameters to be estimated, as $\delta$. For the time being, we will focus on $\theta=0.5$, the conditional median, or what is also referred to as the LAD estimator, but slope parameters may vary at different quantiles of the conditional growth rate distribution. This is particularly relevant for us to assess the role of CEO age in organic growth across the entire spectrum of growth rates, and because as shown in the tails of the distribution of Figure 2, there could be appreciable differences in growth rates among firms with CEOs of different ages.

Table 3 shows the estimates for Eq. 2 by means of LAD. In col. (1), we introduce only the main

\footnotetext{
${ }^{21}$ While the dependent variable has been calculated by means of the growth rate per unit of time over the period 2009-2014 (as shown in Eq. 1), all control variables built from BvD's Amadeus have been calculated as averages of available yearly information during the period 2001-2008, to minimize the impact of the missing yearly information

${ }^{22}$ We cross-refer the reader to Table A.1 in the Online Appendix, for the taxonomy of manufacturing industries considered in the empirical analysis
}

explanatory variable together with the vector countryindustry dummies. From col. (2) to col. (8), we add the other firm characteristics hierarchically, giving col. (8) the richer specification. Once controlled for a large set of firm characteristics, the growth rate of firms managed by CEOs younger than 45 is around $0.7 \log$ points higher than the growth rate of firms managed by older CEOs, at the median of the conditional growth rate distribution. The magnitude of this coefficient is stable across specifications.

As for the coefficients associated with the control variables, it is worth mentioning that firm size and age show the expected negative sign, that is, younger and smaller firms have grown more than their older and larger counterparts in the period 2009-2014 (see Barba Navaretti et al., 2014; Haltiwanger et al., 2013). Most

${ }^{23}$ Quantile regressions with heteroskedastic-robust standard errors have been estimated by using the Stata package qreg2 written by J. A. F. Machado, P. M. D. C Parente and J. M. C. Santos Silva

${ }^{24}$ Equation 3 is the objective function and is an asymmetric linear loss function. $\theta$ is the quantile defined as $Q_{\theta}\left(\overline{g r}_{i, 2009-2014} \mid X_{i}\right) \equiv \inf \left\{\overline{g r}_{i, 2009-2014}: F\left(\overline{g r}_{i, 2009-2014} \mid X_{i}\right) \geq \theta\right\}$, in which $0<\theta<1$ and $\overline{g r}_{i, 2009-2014}$ is a sample from a random variable with a conditional distribution function $F\left(\cdot \mid X_{i}\right)$. 
notably, since smaller and younger firms are more likely to appoint younger CEOs, in col. (2) we notice that when controlling for firm size and age, the coefficient on CEO age drops slightly. However, our results show that if we compare two firms of the same size and age, the firm with a CEO younger than 45 will have $0.59 \mathrm{log}$ points higher sales growth. While the debt-to-assets ratio is never significant in explaining the growth of the firm at the median of the conditional distribution of growth rates, more profitable firms (higher ROE) show higher growth rates. This result may concurrently be explained by models that analyze the role of financing constraints for firms' investment (Fazzari et al., 1988), and by the evolutionary models of the "growth of the fitter" (Coad, 2007). Ceteris paribus, more innovative (especially in terms of process innovation) and internationalized firms (in terms of the number of countries to which the firm exports, and the status of the importer), have grown faster in the period 2009-2014 (see Coad \& Rao, 2008; Grazzi \& Moschella, 2018). Finally, while the share of graduate workers is not associated with higher growth, both quality certification and product range widening strategies are.

As discussed in Section 2, CEO age may be correlated with other characteristics of top executives that relate to higher firm growth. Thus, to limit any omitted variable bias problem, we further enrich our empirical specification with a vector of CEO characteristics observed at the beginning of the period. Specifically, we include the information on CEO gender and proxies of risk-tolerance, over-confidence, and international experience. Table 4 shows that while over-confidence is positively correlated with firm growth, risk-tolerance and CEO gender are not, and the international experience of the executives is only marginally significant. Simultaneously, while a small decrease in the CEO age coefficient is appreciable, the growth rate of firms managed by a CEO younger than 45 is around $0.66 \mathrm{log}$ points higher than the growth rate of firms managed by an older CEO, at the median of the conditional distribution of growth rates.

These results support the view that organic growth is the outcome of investing in high-growth segments of activity, creating new products, services, and business models (Ahuja et al., 2017). These results are also consistent with the idea that younger CEOs may not necessarily boost organic growth because of their higher risk tolerance. Indeed, among our control variables, we have several measures that allow partial control for the higher-risk tolerance of younger CEOs. In particular, we include the propensity not to hedge against exchange rate risk, a measure of over-confidence and CEO characteristics that are traditionally associated with more risk-taking, such as CEO gender (male) and the international experience of the executives. In Section A.3.5 in the Online Appendix, we control for another proxy for risk, by including the coefficient of variation in turnover (i.e., the ratio of the standard deviation of sales to the average sales figure) over the period 2009-2014.

From the first set of econometric results, we obtain evidence that CEO age is negatively correlated with organic growth in the period 2009-2014. We submit that even conditional on younger CEOs being more prone to risk-taking, these results are consistent with the arguments developed in Section 2 and, thus, lead to the formulation of H1. Young CEOs have the incentive to boost organic growth not necessarily because of a lower risk aversion, as growth can also be achieved by relatively low-risk strategies, like aggressive pricing, which allows market share gain and boost firm size. This will signal the value of the CEO (managerial signaling) to the market and provide the justification for an increase in compensation due to the higher complexity associated with managing a larger company (compensation incentive). Simultaneously, since this strategy may lower the firm's profit margins, firm growth may occur at the expense of profitability maximization, and can thus create a wedge between the young CEO and the shareholders' incentives.

When the quantile regression estimator in Eq. 3 is applied at different percentiles (p10, p25, p50, p75, p90) of the conditional growth rates distribution, we uncover that the relationship is statistically relevant for the episodes located on the right tail of the distribution, while it is not significant for the episodes located on the left tail (Table 5).

This result is consistent with earlier evidence showing that CEO compensation is more sensitive to episodes of firm expansion than to episodes of firm contraction (Bebchuck \& Grinstein, 2005). In other words, to the extent that young CEOs' compensation grows when their firm grows in size, but does not decline when their firm shrinks, they have an incentive to boost growth, but not to prevent downsizing. This may map into larger differences in growth between firms managed by younger CEOs and those with older CEOs, at the higher percentiles of the conditional distribution (i.e., above the median, which is close to zero). Instead, 
Table 3 LAD (median) regressions of sales growth rates (per unit of time) in the period 2009-2014 on firm characteristics.

\begin{tabular}{|c|c|c|c|c|c|c|c|c|}
\hline & (1) & (2) & (3) & (4) & $(5)$ & (6) & (7) & (8) \\
\hline CEO (<45 y.o. $)$ & $\begin{array}{l}0.0073 * * * \\
(0.0020)\end{array}$ & $\begin{array}{l}0.0059 * * * \\
(0.0022)\end{array}$ & $\begin{array}{l}0.0067 * * * \\
(0.0024)\end{array}$ & $\begin{array}{l}0.0066^{* * * *} \\
(0.0023)\end{array}$ & $\begin{array}{l}0.0059 * * \\
(0.0024)\end{array}$ & $\begin{array}{l}0.0063 * * * \\
(0.0024)\end{array}$ & $\begin{array}{l}0.0062 * * \\
(0.0026)\end{array}$ & $\begin{array}{l}0.0072 * * * \\
(0.0024)\end{array}$ \\
\hline Firm size: sales (log) & & $\begin{array}{l}-0.0010 \\
(0.0007)\end{array}$ & $\begin{array}{l}-0.0007 \\
(0.0008)\end{array}$ & $\begin{array}{l}-0.0007 \\
(0.0008)\end{array}$ & $\begin{array}{l}-0.0016^{* *} \\
(0.0008)\end{array}$ & $\begin{array}{l}-0.0037 \text { *** } \\
(0.0008)\end{array}$ & $\begin{array}{l}-0.0037 * * * \\
(0.0009)\end{array}$ & $\begin{array}{l}-0.0038^{* * * *} \\
(0.0009)\end{array}$ \\
\hline Firm age $(+1, \log )$ & & $\begin{array}{l}-0.0054 * * * \\
(0.0011)\end{array}$ & $\begin{array}{l}-0.0057 * * * \\
(0.0012)\end{array}$ & $\begin{array}{l}-0.0057 * * * \\
(0.0012)\end{array}$ & $\begin{array}{l}-0.0055^{* * *} \\
(0.0013)\end{array}$ & $\begin{array}{l}-0.0059 * * * \\
(0.0012)\end{array}$ & $\begin{array}{l}-0.0056^{* * * *} \\
(0.0013)\end{array}$ & $\begin{array}{l}-0.0055^{* * *} \\
(0.0013)\end{array}$ \\
\hline ROE & & & $\begin{array}{l}0.0002 * * * \\
(0.0000)\end{array}$ & $\begin{array}{l}0.0002 * * * \\
(0.0000)\end{array}$ & $\begin{array}{l}0.0001^{* * *} \\
(0.0000)\end{array}$ & $\begin{array}{l}0.0002 * * * \\
(0.0000)\end{array}$ & $\begin{array}{l}0.0002^{* * *} \\
(0.0000)\end{array}$ & $\begin{array}{l}0.0001 * * * \\
(0.0000)\end{array}$ \\
\hline Debt to assets ratio & & & & $\begin{array}{l}0.0002 \\
(0.0015)\end{array}$ & $\begin{array}{l}-0.0006 \\
(0.0019)\end{array}$ & $\begin{array}{l}-0.0008 \\
(0.0020)\end{array}$ & $\begin{array}{l}-0.0007 \\
(0.0014)\end{array}$ & $\begin{array}{l}-0.0010 \\
(0.0014)\end{array}$ \\
\hline Product innovation & & & & & $\begin{array}{l}0.0047 * * \\
(0.0022)\end{array}$ & $\begin{array}{l}0.0023 \\
(0.0022)\end{array}$ & $\begin{array}{l}0.0027 \\
(0.0023)\end{array}$ & $\begin{array}{l}0.0015 \\
(0.0023)\end{array}$ \\
\hline Process innovation & & & & & $\begin{array}{l}0.0093 * * * \\
(0.0022)\end{array}$ & $\begin{array}{l}0.0089 * * * \\
(0.0022)\end{array}$ & $\begin{array}{l}0.0109 * * * \\
(0.0022)\end{array}$ & $\begin{array}{l}0.0099 * * * \\
(0.0022)\end{array}$ \\
\hline Exporter to $1-5$ countries & & & & & & $\begin{array}{l}0.0045^{*} \\
(0.0026)\end{array}$ & $\begin{array}{l}0.0046 \\
(0.0028)\end{array}$ & $\begin{array}{l}0.0039 \\
(0.0028)\end{array}$ \\
\hline Exporter to 6-30 countries & & & & & & $\begin{array}{l}0.0116^{* * *} \\
(0.0028)\end{array}$ & $\begin{array}{l}0.0112 * * * \\
(0.0029)\end{array}$ & $\begin{array}{l}0.0103 * * * \\
(0.0029)\end{array}$ \\
\hline Exporter to $>31$ countries & & & & & & $\begin{array}{l}0.0283^{* * * *} \\
(0.0050)\end{array}$ & $\begin{array}{l}0.0250^{* * * *} \\
(0.0057)\end{array}$ & $\begin{array}{l}0.0234 * * * \\
(0.0056)\end{array}$ \\
\hline Importer & & & & & & $\begin{array}{l}0.0057 * * \\
(0.0023)\end{array}$ & $\begin{array}{l}0.0040 \\
(0.0024)\end{array}$ & $\begin{array}{l}0.0042 * \\
(0.0025)\end{array}$ \\
\hline $\begin{array}{l}\text { Share of university } \\
\text { graduates in the } \\
\text { workforce }\end{array}$ & & & & & & & $\begin{array}{l}0.0140 \\
(0.0103)\end{array}$ & $\begin{array}{l}0.0068 \\
(0.0090)\end{array}$ \\
\hline Quality certification & & & & & & & & $\begin{array}{l}0.0069 * * * \\
(0.0024)\end{array}$ \\
\hline Product range widened & & & & & & & & $\begin{array}{l}0.0041 * \\
(0.0024)\end{array}$ \\
\hline Constant & $\begin{array}{l}0.0736^{* * * *} \\
(0.0104)\end{array}$ & $\begin{array}{l}0.0426^{* * * *} \\
(0.0148)\end{array}$ & $\begin{array}{l}0.1761 * * * \\
(0.0135)\end{array}$ & $\begin{array}{l}0.1757 * * * \\
(0.0137)\end{array}$ & $\begin{array}{l}0.1708 * * * \\
(0.0137)\end{array}$ & $\begin{array}{l}-0.7216^{* * * *} \\
(0.0153)\end{array}$ & $\begin{array}{l}0.0626^{* * *} \\
(0.0174)\end{array}$ & $\begin{array}{l}0.0558 * * * \\
(0.0176)\end{array}$ \\
\hline Country*Industry FE & Yes & Yes & Yes & Yes & Yes & Yes & Yes & Yes \\
\hline Firms & 7196 & 7194 & 6465 & 6462 & 6461 & 6147 & 5825 & 5822 \\
\hline $\begin{array}{l}\text { Goodness of fit: Corr.(gr, } \\
\text { pr_gr)^ } 2\end{array}$ & 0.0671 & 0.0705 & 0.0821 & 0.0827 & 0.0851 & 0.0923 & 0.0840 & 0.0852 \\
\hline
\end{tabular}

All regressions include country-industry fixed effects, where industries are defined at the 2-digit NACE rev.2 classification. Coefficients of country*industry dummies are not reported to save space. Full tables are available from authors upon request. Heteroskedastic-robust standard errors are reported in parentheses (Machado et al., 2011). Statistical significance at the $10 \%, 5 \%$ and $1 \%$ level is indicated by *** and $* * *$, respectively.

these differences disappear among firms whose growth rate is below the median. Moreover, the effect is stronger at the highest percentiles (p90) of the right tail of the distribution, i.e., for episodes of high growth. This result is coherent with the results shown by Yim (2013) on the negative relationship between CEO age and acquisitions, which the author found significant only for episodes of relevant acquisitions that is a deal value exceeding $5 \%$ of the firm's market capitalization, which would more likely affect CEO compensation. 
Table 4 LAD (median) regressions of sales growth rates (per unit of time) in the period 2009-2014 on firm and CEO characteristics

\begin{tabular}{|c|c|c|c|c|c|}
\hline & (1) & (2) & (3) & (4) & $(5)$ \\
\hline CEO (< 45 y.o. $)$ & $\begin{array}{l}0.0069 * * * \\
(0.0024)\end{array}$ & $\begin{array}{l}0.0068^{* * * *} \\
(0.0025)\end{array}$ & $\begin{array}{l}0.0067 * * * \\
(0.0025)\end{array}$ & $\begin{array}{l}0.0066^{* * * *} \\
(0.0025)\end{array}$ & $\begin{array}{l}0.0066^{* * *} \\
(0.0025)\end{array}$ \\
\hline Firm size: sales $(\log )$ & $\begin{array}{l}-0.0039 * * * \\
(0.0009)\end{array}$ & $\begin{array}{l}-0.0037 * * * \\
(0.0009)\end{array}$ & $\begin{array}{l}-0.0043^{* * * *} \\
(0.0010)\end{array}$ & $\begin{array}{l}-0.0044 * * * \\
(0.0010)\end{array}$ & $\begin{array}{l}-0.0043 \text { *** } \\
(0.0010)\end{array}$ \\
\hline Firm age $(+1, \log )$ & $\begin{array}{l}-0.0054^{* * *} \\
(0.0013)\end{array}$ & $\begin{array}{l}-0.0056^{* * *} \\
(0.0013)\end{array}$ & $\begin{array}{l}-0.0054 * * * \\
(0.0014)\end{array}$ & $\begin{array}{l}-0.0054 * * * \\
(0.0013)\end{array}$ & $\begin{array}{l}-0.0052^{* * *} \\
(0.0013)\end{array}$ \\
\hline ROE & $\begin{array}{l}0.0001 * * * \\
(0.0000)\end{array}$ & $\begin{array}{l}0.0002 * * * \\
(0.0000)\end{array}$ & $\begin{array}{l}0.0001 * * * \\
(0.0000)\end{array}$ & $\begin{array}{l}0.0001 * * * \\
(0.0000)\end{array}$ & $\begin{array}{l}0.0002 * * * \\
(0.0000)\end{array}$ \\
\hline Debt to assets ratio & $\begin{array}{l}-0.0007 \\
(0.0014)\end{array}$ & $\begin{array}{l}-0.0015 \\
(0.0014)\end{array}$ & $\begin{array}{l}-0.0016 \\
(0.0027)\end{array}$ & $\begin{array}{l}-0.0012 \\
(0.0014)\end{array}$ & $\begin{array}{l}0.0003 \\
(0.0057)\end{array}$ \\
\hline Product innovation & $\begin{array}{l}0.0016 \\
(0.0023)\end{array}$ & $\begin{array}{l}0.0005 \\
(0.0024)\end{array}$ & $\begin{array}{l}0.0015 \\
(0.0025)\end{array}$ & $\begin{array}{l}0.0013 \\
(0.0024)\end{array}$ & $\begin{array}{l}0.0002 \\
(0.0024)\end{array}$ \\
\hline Process innovation & $\begin{array}{l}0.0098 * * * \\
(0.0022)\end{array}$ & $\begin{array}{l}0.0083 * * * \\
(0.0022)\end{array}$ & $\begin{array}{l}0.0103 * * * \\
(0.0023)\end{array}$ & $\begin{array}{l}0.0092 * * * \\
(0.0022)\end{array}$ & $\begin{array}{l}0.0084 * * * \\
(0.0023)\end{array}$ \\
\hline Exporter to $1-5$ countries & $\begin{array}{l}0.0037 \\
(0.0028)\end{array}$ & $\begin{array}{l}0.0038 \\
(0.0029)\end{array}$ & $\begin{array}{l}0.0036 \\
(0.0030)\end{array}$ & $\begin{array}{l}0.0037 \\
(0.0029)\end{array}$ & $\begin{array}{l}0.0030 \\
(0.0030)\end{array}$ \\
\hline Exporter to 6-30 countries & $\begin{array}{l}0.0102 * * * \\
(0.0029)\end{array}$ & $\begin{array}{l}0.0107 * * * \\
(0.0029)\end{array}$ & $\begin{array}{l}0.0101 * * * \\
(0.0034)\end{array}$ & $\begin{array}{l}0.0106^{* * * *} \\
(0.0030)\end{array}$ & $\begin{array}{l}0.0084 * * * \\
(0.0032)\end{array}$ \\
\hline Exporter to $>31$ countries & $\begin{array}{l}0.0231 * * * \\
(0.0057)\end{array}$ & $\begin{array}{l}0.0246 * * * \\
(0.0058)\end{array}$ & $\begin{array}{l}0.0265 * * * \\
(0.0063)\end{array}$ & $\begin{array}{l}0.0241 * * * \\
(0.0058)\end{array}$ & $\begin{array}{l}0.0253 * * * \\
(0.0061)\end{array}$ \\
\hline Importer & $\begin{array}{l}0.0040 \\
(0.0025)\end{array}$ & $\begin{array}{l}0.0042 * \\
(0.0025)\end{array}$ & $\begin{array}{l}0.0033 \\
(0.0026)\end{array}$ & $\begin{array}{l}0.0037 \\
(0.0025)\end{array}$ & $\begin{array}{l}0.0045^{*} \\
(0.0025)\end{array}$ \\
\hline Share of university graduates in the workforce & $\begin{array}{l}0.0085 \\
(0.0099)\end{array}$ & $\begin{array}{l}0.0126 \\
(0.0100)\end{array}$ & $\begin{array}{l}0.0127 \\
(0.0100)\end{array}$ & $\begin{array}{l}0.0098 \\
(0.0096)\end{array}$ & $\begin{array}{l}0.0128 \\
(0.0096)\end{array}$ \\
\hline Quality certification & $\begin{array}{l}0.0069 * * * \\
(0.0024)\end{array}$ & $\begin{array}{l}0.0066^{* * *} \\
(0.0023)\end{array}$ & $\begin{array}{l}0.0061 * * \\
(0.0024)\end{array}$ & $\begin{array}{l}0.0074 * * * \\
(0.0024)\end{array}$ & $\begin{array}{l}0.0066^{* * *} \\
(0.0024)\end{array}$ \\
\hline Product range widened & $\begin{array}{l}0.0040 * \\
(0.0023)\end{array}$ & $\begin{array}{l}0.0056^{* *} \\
(0.0023)\end{array}$ & $\begin{array}{l}0.0042 * \\
(0.0025)\end{array}$ & $\begin{array}{l}0.0037 \\
(0.0024)\end{array}$ & $\begin{array}{l}0.0041^{*} \\
(0.0024)\end{array}$ \\
\hline Male CEO & $\begin{array}{l}0.0037 \\
(0.0035)\end{array}$ & & & & $\begin{array}{l}0.0027 \\
(0.0035)\end{array}$ \\
\hline Over-confident & & $\begin{array}{l}0.0077 * * * \\
(0.0023)\end{array}$ & & & $\begin{array}{l}0.0093 * * * \\
(0.0022)\end{array}$ \\
\hline Risk-tolerant & & & $\begin{array}{l}0.0028 \\
(0.0032)\end{array}$ & & $\begin{array}{l}0.0047 \\
(0.0030)\end{array}$ \\
\hline International experience of the executives & & & & $\begin{array}{l}0.0050 \\
(0.0033)\end{array}$ & $\begin{array}{l}0.0059 * \\
(0.0035)\end{array}$ \\
\hline Constant & $\begin{array}{l}0.2258 * * * \\
(0.0169)\end{array}$ & $\begin{array}{l}0.2241 * * * \\
(0.0168)\end{array}$ & $\begin{array}{l}0.0786^{* * *} \\
(0.0163)\end{array}$ & $\begin{array}{l}0.0239 \\
(0.0165)\end{array}$ & $\begin{array}{l}0.0613 * * * \\
(0.0171)\end{array}$ \\
\hline Country*Industry FE & Yes & Yes & Yes & Yes & Yes \\
\hline Firms & 5821 & 5818 & 5667 & 5770 & 5613 \\
\hline Goodness of fit: Corr.(gr, pr gr $)^{\wedge} 2$ & 0.0851 & 0.0860 & 0.0772 & 0.0826 & 0.0763 \\
\hline
\end{tabular}

All regressions include country-industry fixed effects, where industries are defined at the 2-digit NACE rev.2 classification. Coefficients of country*industry dummies are not reported to save space. Full tables are available from authors upon request. Heteroskedastic-robust standard errors are reported in parentheses (Machado et al., 2011). Statistical significance at the 10, 5, and $1 \%$ level is indicated by ***, and ***, respectively 
Table 5 Quantile regression of the sales growth rates (per unit of time) in the period 2009-2014 on firm and CEO characteristics

\begin{tabular}{|c|c|c|c|c|c|}
\hline & (1) & (2) & (3) & (4) & (5) \\
\hline & p10 & $\mathrm{p} 25$ & p50 & p75 & p90 \\
\hline \multirow[t]{2}{*}{ CEO (< 45 y.o. $)$} & -0.0014 & 0.0024 & $0.0066^{* * *}$ & $0.0124 * * *$ & $0.0141 * * *$ \\
\hline & $(0.0074)$ & $(0.0044)$ & $(0.0025)$ & $(0.0029)$ & $(0.0042)$ \\
\hline \multirow[t]{2}{*}{ Firm size: sales (log) } & $-0.0081 * *$ & $-0.0058 * * *$ & $-0.0043 * * *$ & $-0.0061 * * *$ & $-0.0089 * * *$ \\
\hline & $(0.0035)$ & $(0.0019)$ & $(0.0010)$ & $(0.0012)$ & $(0.0017)$ \\
\hline \multirow[t]{2}{*}{ Firm age $(+1, \log )$} & 0.0001 & $-0.0038^{*}$ & $-0.0052 * * *$ & $-0.0094 * * *$ & $-0.0118 * * *$ \\
\hline & $(0.0036)$ & $(0.0020)$ & $(0.0013)$ & $(0.0015)$ & $(0.0023)$ \\
\hline \multirow[t]{2}{*}{ ROE } & $0.0001 *$ & $-0.0001 * * *$ & $0.0002 * * *$ & $0.0001 * * *$ & $0.0000^{*}$ \\
\hline & $(0.0001)$ & $(0.0000)$ & $(0.0000)$ & $(0.0000)$ & $(0.0000)$ \\
\hline \multirow[t]{2}{*}{ Debt to assets ratio } & -0.0218 & -0.0042 & 0.0003 & 0.0063 & 0.0053 \\
\hline & $(0.0169)$ & $(0.0079)$ & $(0.0057)$ & $(0.0071)$ & $(0.0099)$ \\
\hline \multirow[t]{2}{*}{ Product innovation } & -0.0070 & -0.0029 & 0.0002 & 0.0042 & 0.0014 \\
\hline & $(0.0073)$ & $(0.0040)$ & $(0.0024)$ & $(0.0028)$ & $(0.0047)$ \\
\hline \multirow[t]{2}{*}{ Process innovation } & $0.0162 * *$ & $0.0135 * * *$ & $0.0084 * * *$ & $0.0074 * * *$ & $0.0084 * *$ \\
\hline & $(0.0072)$ & $(0.0039)$ & $(0.0023)$ & $(0.0026)$ & $(0.0042)$ \\
\hline \multirow[t]{2}{*}{ Exporter to $1-5$ countries } & -0.0025 & -0.0011 & 0.0030 & $0.0086^{* * *}$ & $0.0113 * *$ \\
\hline & $(0.0076)$ & $(0.0047)$ & $(0.0030)$ & $(0.0033)$ & $(0.0047)$ \\
\hline \multirow[t]{2}{*}{ Exporter to 6-30 countries } & 0.0168 & $0.0092 *$ & $0.0084 * * *$ & $0.0100 * * *$ & $0.0140 * * *$ \\
\hline & $(0.0108)$ & $(0.0056)$ & $(0.0032)$ & $(0.0038)$ & $(0.0051)$ \\
\hline \multirow[t]{2}{*}{ Exporter to $>31$ countries } & 0.0322 & $0.0300 * * *$ & $0.0253 * * *$ & $0.0195 * * *$ & $0.0194 *$ \\
\hline & $(0.0204)$ & $(0.0085)$ & $(0.0061)$ & $(0.0059)$ & $(0.0109)$ \\
\hline \multirow[t]{2}{*}{ Importer } & 0.0027 & 0.0050 & $0.0045^{*}$ & $0.0066^{* *}$ & 0.0013 \\
\hline & $(0.0068)$ & $(0.0036)$ & $(0.0025)$ & $(0.0027)$ & $(0.0035)$ \\
\hline \multirow[t]{2}{*}{ Share of university graduates in the workforce } & 0.0153 & $0.0235^{*}$ & 0.0128 & $0.0413 * * *$ & $0.0420 * * *$ \\
\hline & $(0.0370)$ & $(0.0135)$ & $(0.0096)$ & $(0.0138)$ & $(0.0162)$ \\
\hline \multirow[t]{2}{*}{ Quality certification } & 0.0021 & 0.0021 & $0.0066 * * *$ & $0.0060 * *$ & 0.0060 \\
\hline & $(0.0066)$ & $(0.0039)$ & $(0.0024)$ & $(0.0026)$ & $(0.0038)$ \\
\hline \multirow[t]{2}{*}{ Product range widened } & $0.0124 * *$ & $0.0075^{* *}$ & $0.0041^{*}$ & 0.0041 & 0.0027 \\
\hline & $(0.0058)$ & $(0.0035)$ & $(0.0024)$ & $(0.0026)$ & $(0.0036)$ \\
\hline \multirow[t]{2}{*}{ Male CEO } & -0.0055 & 0.0004 & 0.0027 & $0.0084 * *$ & 0.0092 \\
\hline & $(0.0119)$ & $(0.0069)$ & $(0.0035)$ & $(0.0039)$ & $(0.0062)$ \\
\hline \multirow[t]{2}{*}{ Over-confident } & 0.0059 & 0.0047 & $0.0093 * * *$ & $0.0094 * * *$ & $0.0091 * * *$ \\
\hline & $(0.0064)$ & $(0.0032)$ & $(0.0022)$ & $(0.0025)$ & $(0.0034)$ \\
\hline \multirow[t]{2}{*}{ Risk-tolerant } & 0.0061 & 0.0010 & 0.0047 & 0.0009 & $-0.0074 *$ \\
\hline & $(0.0079)$ & $(0.0045)$ & $(0.0030)$ & $(0.0030)$ & $(0.0044)$ \\
\hline \multirow[t]{2}{*}{ International experience of the executives } & -0.0072 & 0.0002 & $0.0059 *$ & 0.0020 & 0.0038 \\
\hline & $(0.0109)$ & $(0.0055)$ & $(0.0035)$ & $(0.0031)$ & $(0.0042)$ \\
\hline \multirow[t]{2}{*}{ Constant } & $0.1109 * *$ & $0.1081 * * *$ & $0.0613 * * *$ & $0.0858 * * *$ & $0.1357 * * *$ \\
\hline & $(0.0457)$ & $(0.0267)$ & $(0.0171)$ & $(0.0150)$ & $(0.0222)$ \\
\hline Country*Industry FE & Yes & Yes & Yes & Yes & Yes \\
\hline Firms & 5613 & 5613 & 5613 & 5613 & 5613 \\
\hline Goodness of fit: Corr.(gr, pr_gr)^2 & 0.0560 & 0.0775 & 0.0763 & 0.0605 & 0.0373 \\
\hline
\end{tabular}

All regressions include country-industry fixed effects, where industries are defined at the 2-digit NACE rev.2 classification. Coefficients of country*industry dummies are not reported to save space. Full tables are available from authors upon request. Heteroskedastic-robust standard errors are reported in parentheses (Machado et al., 2011). Statistical significance at the 10,5 and $1 \%$ level is indicated by ***, and ***, respectively 
In Section A.3 in the online appendix, we conduct a battery of robustness checks and explore (i) different time horizons over which the growth rate is calculated, to lessen the issue related to a possible (unobserved) turnover of the CEO (Section A.3.1 and Table A.3); (ii) issues relating to the timing of CEO appointment, by controlling for firm past-growth and by running the baseline model on the sub-sample of firms established within the last five to ten years before 2009 (Section A.3.2 and Tables A.4, A.5); (iii) a possible reverse-causality bias, from firms with certain characteristics and growth trajectories which choose a young CEO, by means of a propensity score matched (PSM) sample analysis (Section A.3.3 and Tables A.6, A.7, A.8); (iv) the validity of the age threshold set at 45 (Section A.3.4 and Table A.9); (v) the possible role of higher risk-tolerance of younger CEOs (Section A.3.5 and Table A.10), by controlling for the volatility in sales (as proxied by the coefficient of variation in firm turnover over the period 2009-2014); (vi) the possible confounding effect of the education level of the younger cohorts of managers (Section A.3.6 and Table A.11); (vii) the robustness of our findings with the exclusion of firms engaged in M\&As (Section A.3.7 and Table A.12); and (viii) the existence of country specificities in the relationship between CEO age and firm growth (Section A.3.8 and Table A.13). Overall, the correlation between CEO age and firm organic growth is robust to all these tests. In Section 4.2, we inquire, through the lens of the P-A framework, into the mechanisms that may enhance or moderate the relationship between $\mathrm{CEO}$ age and organic growth.

\subsection{Identifying the mechanism in a P-A framework}

Section 2 highlighted that the higher growth achieved by firms managed by younger CEOs could be the result of a specific set of incentives for top managers, which may diverge from shareholders' targets. We have argued that younger CEOs may be motivated to boost firm growth to signal their talent and to increase their compensation. However, shareholders are normally more interested in profit maximization, than the growth of sales and market share. In Table 6 we provide evidence of this potential divergence of interests. In fact, while firms managed by younger CEOs show higher growth of total assets (panel A), they do not show any difference in the growth of operating profits (panel B).
This suggests that strategies pursued by younger CEOs may place a wedge between their own targets and the interests of their shareholders. As discussed in Section 2, this divergence should be moderated by the ability of shareholders to monitor CEOs' decisions. It is established in the literature that in firms with more concentrated ownership, the shareholders can monitor CEOs more effectively; therefore, we use this to test the arguments leading to H2. In Tables 7 and 8, we estimate two variants of Eq. 4 as below:

Table 6 Quantile regression of total assets growth (panel A) and profit growth (panel B) (per unit of time) in the period 2009-2014 on firm-level and CEO characteristics.

\begin{tabular}{|c|c|c|c|}
\hline \multirow{2}{*}{$\begin{array}{l}\text { Panel A: Total assets } \\
\text { growth }\end{array}$} & (1) & (2) & (3) \\
\hline & $\mathrm{p} 50$ & p75 & p90 \\
\hline \multirow[t]{2}{*}{ CEO (< 45 y.o. $)$} & $0.0052 *$ & $0.0079 * * *$ & $0.0105 * * *$ \\
\hline & $(0.0029)$ & $(0.0030)$ & $(0.0040)$ \\
\hline $\begin{array}{l}\text { Firm and CEO } \\
\text { characteristics }\end{array}$ & Yes & Yes & Yes \\
\hline \multirow[t]{2}{*}{ Constant } & $0.0884 * * *$ & $0.0980 * * *$ & $0.1154 * * *$ \\
\hline & $(0.0170)$ & $(0.0157)$ & $(0.0187)$ \\
\hline Country*Industry FE & Yes & Yes & Yes \\
\hline Firms & 6103 & 6103 & 6103 \\
\hline $\begin{array}{l}\text { Goodness of fit: Corr.(gr, } \\
\text { pr_gr })^{\wedge} 2\end{array}$ & 0.0442 & 0.0367 & 0.0296 \\
\hline \multirow[t]{2}{*}{ Panel B: Profit growth } & (1) & (2) & (3) \\
\hline & $\mathrm{p} 50$ & p75 & p90 \\
\hline \multirow[t]{2}{*}{ CEO (< 45 y.o.) } & 0.0096 & -0.0147 & -0.0162 \\
\hline & $(0.0109)$ & $(0.0179)$ & $(0.0537)$ \\
\hline Firm and CEO characteristics & Yes & Yes & Yes \\
\hline \multirow[t]{2}{*}{ Constant } & 0.1017 & -0.1410 & $-0.8185^{* * *}$ \\
\hline & $(0.0782)$ & $(0.2246)$ & $(0.2920)$ \\
\hline Country*Industry FE & Yes & Yes & Yes \\
\hline Firms & 5569 & 5569 & 5569 \\
\hline $\begin{array}{l}\text { Goodness of fit: Corr.(gr, } \\
\text { pr_gr)^2 }\end{array}$ & 0.0005 & 0.0005 & 0.0007 \\
\hline
\end{tabular}

All regressions include a vector of firm and CEO characteristics plus country-industry fixed effects, where industries are defined at the 2-digit NACE rev.2 classification. Coefficients of country*industry dummies and the vector of controls are not reported to save space. Full tables are available from authors upon request. Heteroskedastic-robust standard errors are reported in parentheses (Machado et al., 2011). Statistical significance at the $10 \%, 5 \%$ and $1 \%$ level is indicated by $* * *$ and $* * *$, respectively 
Table 7 The role of monitoring (concentrated ownership) for the relationship between CEO age and firm growth

\begin{tabular}{|c|c|c|c|c|c|}
\hline & (1) & (2) & (3) & (4) & $(5)$ \\
\hline & p50 & $\mathrm{p} 50$ & $\mathrm{p} 50$ & p75 & p90 \\
\hline \multirow[t]{2}{*}{ CEO (<45 y.o.) } & $0.0066^{* * *}$ & $0.0057 * *$ & 0.0067 & $0.0159 * *$ & $0.0306 * * *$ \\
\hline & $(0.0025)$ & $(0.0025)$ & $(0.0046)$ & $(0.0068)$ & $(0.0082)$ \\
\hline \multirow[t]{2}{*}{$1^{\text {st }}$ shareholder owns $>=50 \%$ of equity } & & 0.0027 & 0.0028 & 0.0024 & $0.0096 * *$ \\
\hline & & $(0.0024)$ & $(0.0026)$ & $(0.0027)$ & $(0.0038)$ \\
\hline \multirow[t]{2}{*}{ CEO $(<45 \text { y.o. })^{*}\left(1^{\text {st }}\right.$ shareholder owns $>=50 \%$ of equity $)$} & & & -0.0014 & -0.0048 & $-0.0241 * * *$ \\
\hline & & & $(0.0056)$ & $(0.0077)$ & $(0.0092)$ \\
\hline Firm and CEO characteristics & Yes & Yes & Yes & Yes & Yes \\
\hline \multirow[t]{2}{*}{ Constant } & $0.0613 * * *$ & $0.2192 * * *$ & $0.2195 * * *$ & $0.1989 * * *$ & $0.2366^{* * *}$ \\
\hline & $(0.0171)$ & $(0.0178)$ & $(0.0178)$ & $(0.0173)$ & $(0.0210)$ \\
\hline Country*Industry FE & Yes & Yes & Yes & Yes & Yes \\
\hline Firms & 5613 & 5374 & 5374 & 5374 & 5374 \\
\hline Goodness of fit: Corr.(gr, pr_gr)^2 & 0.0763 & 0.0723 & 0.0725 & 0.0565 & 0.0372 \\
\hline \multicolumn{6}{|l|}{ Statistical tests } \\
\hline H0: Young/dispersed = Young/concentrated ( $\mathrm{p}$-value) & & & 0.7754 & 0.7289 & 0.0918 \\
\hline H0: Young/concentrated =Old/concentrated ( $\mathrm{p}$-value) & & & 0.0866 & 0.0008 & 0.1804 \\
\hline
\end{tabular}

All regressions include a vector of firm and CEO characteristics plus country-industry fixed effects, where industries are defined at the 2digit NACE rev.2 classification. Coefficients of country*industry dummies and the vector of controls are not reported to save space. Full tables are available from authors upon request. Heteroskedastic-robust standard errors are reported in parentheses (Machado et al., 2011). Statistical significance at the 10,5 , and $1 \%$ level is indicated by $* * *$ and $* * *$, respectively

Table 8 The role of monitoring (concentrated ownership) for the relationship between CEO age and firm growth.

\begin{tabular}{|c|c|c|c|c|c|}
\hline & (1) & (2) & (3) & (4) & $(5)$ \\
\hline & $\mathrm{p} 50$ & p50 & $\mathrm{p} 50$ & $\mathrm{p} 75$ & p90 \\
\hline \multirow[t]{2}{*}{ CEO (<45 y.o. $)$} & $0.0066^{* * *}$ & $0.0054 * *$ & 0.0070 & $0.0175 * *$ & $0.0407 * * *$ \\
\hline & $(0.0025)$ & $(0.0025)$ & $(0.0059)$ & $(0.0077)$ & $(0.0112)$ \\
\hline \multirow[t]{2}{*}{$\%$ of equity owned by the 1 st shareholder } & & -0.0007 & -0.0004 & 0.0011 & $0.0187 * * *$ \\
\hline & & $(0.0042)$ & $(0.0045)$ & $(0.0045)$ & $(0.0064)$ \\
\hline \multirow[t]{2}{*}{ CEO (<45 y.o.)*(\% of equity owned by the 1 st shareholder) } & & & -0.0025 & -0.0068 & $-0.0426 * * *$ \\
\hline & & & $(0.0089)$ & $(0.0106)$ & $(0.0145)$ \\
\hline Firm and CEO characteristics & Yes & Yes & Yes & Yes & Yes \\
\hline \multirow[t]{2}{*}{ Constant } & $0.0613^{* * *}$ & $0.2216 * * *$ & $0.0579 * * *$ & $0.0827 * * *$ & $0.1250 * * *$ \\
\hline & $(0.0171)$ & $(0.0180)$ & $(0.0169)$ & $(0.0149)$ & $(0.0187)$ \\
\hline Country*Industry FE & Yes & Yes & Yes & Yes & Yes \\
\hline Firms & 5613 & 5374 & 5374 & 5374 & 5374 \\
\hline Goodness of fit: Corr.(gr, pr_gr)^2 & 0.0763 & 0.0724 & 0.0727 & 0.0565 & 0.0383 \\
\hline
\end{tabular}

All regressions include a vector of firm and CEO characteristics plus country-industry fixed effects, where industries are defined at the 2digit NACE rev.2 classification. Coefficients of country*industry dummies and the vector of controls are not reported to save space. Full tables are available from authors upon request. Heteroskedastic-robust standard errors are reported in parentheses (Machado et al., 2011). Statistical significance at the 10,5 , and $1 \%$ level is indicated by $* * *$ and $* * *$, respectively 


$$
\begin{aligned}
g r_{i}= & \alpha_{\theta}+\beta_{\theta} C E O(<45 \text { y.o. })_{i}+\eta_{\theta} O W N_{i} \\
& +\omega_{\theta} O W N_{i} * C E O(<45 \text { y.o. })_{i}+\delta^{\prime} X_{i} \\
& +\mu_{\theta j} \cdot \tau_{\theta c}+\varepsilon_{\theta i}
\end{aligned}
$$

where $O W N_{i}$ is a measure of ownership concentration. The notation has been simplified by dropping the time period indicator and collapsing the control variables in vector $X_{i}$.

In the first variant of Eq. 6 (Table 7), we interact the CEO age dummy with a dummy that takes a value of one for firms where the first shareholder owns $50 \%$ or more of the firm's equity and zero otherwise. Results show that this interaction indeed negatively moderates the effect of CEO age on firm growth, although the coefficient is significantly different from zero only at the 90th percentile. At the 90th percentile, firms with relatively more dispersed ownership and young CEOs grow faster than their counterparts with young CEOs but more concentrated shareholders $\left(\mathrm{H}_{0}: \eta_{\theta}+\omega_{\theta}=0\right.$, rejected). This suggests that concentrated ownership curbs the incentives of young CEOs to achieve more growth in firm size. Conversely, no difference in growth is found between firms with younger or older CEOs, if ownership is concentrated $\left(\mathrm{H}_{0}: \beta_{\theta}+\omega_{\theta}=0\right.$, not rejected)

In Table 8, we estimate a variant of Eq. 6 , where the measure of ownership concentration is continuous. In particular, we simply introduce the share of equity owned by the first (largest) shareholder into the regression. The results indicate that at the 90th percentile, the degree of ownership concentration negatively moderates the effect of CEO age on firm growth.

\section{Concluding remarks}

We show that the age of CEOs is significantly associated with firm organic growth. In a large sample of mostly small and medium privately held European manufacturing firms, we find that, at the median of the conditional growth rates distribution, the growth in sales (and total assets) per unit of time over the period 2009-2014 was $0.66(0.52) \log$ points higher in firms managed by CEOs younger than 45 . This difference is twice as large if observed at the 90th percentile, suggesting that firms with younger CEOs are more likely to be very fast- growing firms. Our results are robust to the inclusion of a large vector of firm and CEO characteristics, industry-country unobserved heterogeneity, and a wide set of robustness checks, including issues relating to the time horizon and the appointment of CEOs, the educational attainment of younger cohorts of managers, and endogeneity.

The relationship between CEO age and growth could be explained by the higher risk-taking propensity of young CEOs (Falk et al., 2018) - which has already been associated with firms' risky strategies, such as R\&D investments and M\&As (Serfling, 2014; Yim, 2013) _ or by other individual characteristics such as over-confidence, stamina, higher brain-process capacity, and a lesser rule-of-thumb approach to decision making (Besedeš et al., 2012). Indeed, our findings reveal that some $\mathrm{CEO}$ and firm characteristics that are typically associated with risk-taking and overconfidence are also correlated with firm organic growth. However, we argue that, conditional on these characteristics, the negative relation between CEO age and firm organic growth can be explained by the incentive for younger CEOs to boost firm sales and assets, possibly at the expense of profit margins. Indeed, young CEOs want to signal their value and increase firm size, so that an increase in their compensation can be justified. Clearly, this is unlikely to be in the interests of shareholders. Consistent with this interpretation, we find no significant statistical relationship between CEO age and the growth in operating profits. We also provide evidence that in firms characterized by more effective monitoring governance (more concentrated ownership), the relationship between CEO age and firm organic growth is much weaker. We contend that if our results were driven by CEOs' individual characteristics, other than their greater incentive to achieve fast growth, there would be no reason to find weaker results in more closely monitored firms.

This study contributes to the modern literature on industrial dynamics, by offering insights on the role played by the age of the top executive in firm growth, exclusive of the growth effects ensured by the stochastic, structural, financial, and technological firm-level characteristics. Indeed, while the growth effect of firm characteristics such as age, size, efficiency, innovative activities, and those associated with demand factors has been deeply studied, less evidence has been provided on the role played by the characteristics of the individuals who lead the firm. 
These results bear many implications both for policy and governance. First, in many European countries, the management, including board members, is old. In our sample, around $80 \%$ of the firms have CEOs older than 45. This could be a sign of insufficient turnover in management. This gerontocratic approach to firm management, combined with the evidence that firms run by younger CEOs have been growing more (especially in the complex times of the aftermath of the financial crisis of 2009), could explain why European firms are less dynamic than their US counterparts (Bravo-Biosca et al., 2016). Given that the small size of European firms is closely related to the slow path of productivity growth in Europe, faster turnover in management could help reduce allocative inefficiencies and improve gross domestic product (GDP) growth in the aggregate. Furthermore, as firm growth among incumbent firms is the most important source of job creation among OECD countries (Criscuolo et al., 2014), our results suggest that rejuvenating the management can have important aggregate employment and welfare effects.

Second, our evidence supports the view that governance with independent management from shareholders (and looser supervision by the latter) improves firm performance and should be fostered and implemented as a best practice. Of course, policy-makers do not have the power to rejuvenate management, yet a gradual spread of a corporate culture that increasingly emphasizes management turnover, and independence in management will certainly benefit firm performance and the growth of firms (and SMEs in particular) in the long run.

It is worth laying out a few caveats about our analysis. First, even if the main results of our work are robust to checks and provide the readers with a specific channel of causation, the identification of the causal effect of CEO age on firm growth could be sharpened if we had more precise information on the time of CEO appointment and turnover. Indeed, longitudinal information on CEOs may prove useful for future research on this topic. Second, even if the quantile regression model allows us to appreciate the heterogeneity of the relationship between CEO age and firm growth along the entire distribution of growth rates, the results provided only hold for the group of firms that "survive" (do not exit the market) during the entire period (2009-2014). The field of research about quantile regression models with sample selection is very promising (Arellano \& Bonhomme, 2017), but their application is still not fully developed and it is certainly out of the scope of this study. Third, our study would have benefitted from more information on the psychological and cognitive traits of CEOs. This would have allowed us to better disentangle the role of age, from other traits that may be correlated with age and may impact how managers lead their firms.

Acknowledgments We are grateful to the Editor (Saul Estrin), two anonymous reviewers, Daniela Piazzalunga, Carlo Fezzi, and Maria-Teresa Marchica for helpful comments and suggestions. Feedback from the participants at the 10th European Meeting on Applied Evolutionary Economics (Strasbourg, June 2017), 14th European Network on the Economics of the Firm (Pisa, September 2017), Workshop on challenges of innovation policy, (Reus, November 2017), XVI Workshop SIEPI (Ferrara, February 2018) and the EMiL workshop "The modern drivers of firm performance: Intangibles and Connections" (Trento, December 2018), as well as seminars at City University of London, European Bank for Reconstruction and Development, Henley Business School is gratefully acknowledged. The usual disclaimer applies.

Ethics declarations We, the authors, declare that we have no competing interests in terms of employment, prior or current, nor any financial interests or proprietary interests. Neither was any funding received to assist with the preparation of this manuscript. No ethics approval was required in the preparation of our review document.

\section{References}

Aghion, P., \& Stein, J. C. (2008). Growth versus margins: Destabilizing consequences of giving the stock market what it wants. The Journal of Finance, LXIII(3), 1025-1058. https://doi.org/10.1111/j.1540-6261.2008.01351.x.

Ahuja, K., Segel, L. H., \& Perrey, J. (2017). Mastering three strategies of organic growth. The McKinsey Quarterly, 2-8.

Altomonte, C., Aquilante, T., \& Ottaviano, G. I. P. (2012). The triggers of competitiveness: The EFIGE Cross-Country Report. Bruegel Blueprint Series XVII.

Amihud, Y., \& Lev, B. (1981). Risk reduction as a managerial motive for conglomerate mergers. Bell Journal of Economics, 12, 605-617. https://doi.org/10.2307/3003575.

Andrade, G., Mitchell, M., \& Stafford, E. (2001). New evidence and perspectives on mergers. Journal of Economic Perspectives, 15, 103-120. https://doi.org/10.1257 /jep.15.2.103.

Arata, Y. (2019). Firm growth and Laplace distribution: The importance of large jumps. Journal of Economic Dynamics and Control, 103, 63-82. https://doi.org/10.1016/j. jedc.2019.01.009.

Arellano, M., \& Bonhomme, S. (2017). Quantile selection models with an application to understanding changes in wage inequality. Econometrica, 85(1), 1-28. https://doi.org/10.3982 /ECTA14030.

Arrighetti, A. (1994). Entry, growth and survival of manufacturing firms. Small Business Economics, 6, 127-137. https://doi. org/10.1007/BF01065185. 
Barba Navaretti, G., Castellani, D., \& Pieri, F. (2014). Age and firm growth: Evidence from three European countries. Small Business Economics, 43(4), 823-837. https://doi. org/10.1007/s11187-014-9564-6.

Baumol, W. (1959). Business behavior, value and growth. Macmillan.

Bebchuck, L. A., \& Grinstein, Y. (2005). Firm expansion and CEO pay. In NBER Working Paper 11886. National Bureau of Economic Research, Cambridge. https://doi.org/10.2139 /ssrn.838245.

Bebchuck, L. A., \& Stole, L. A. (1993). Do short-term objectives lead to under- or overinvestment in long-term projects? The Journal of Finance, 48, 719-729. https://doi.org/10.1111 /j.1540-6261.1993.tb04735.x.

Belenzon, S., Shamshur, A., \& Zarutskie, R. (2019). CEO's age and the performance of closely held firms. Strategic Management Journal, 40, 917-944. https://doi.org/10.1002 /smj.3003.

Bertrand, M., \& Schoar, A. (2003). Managing with style: The effect of managers on firm policies. Quarterly Journal of Economics, 118, 1169-1208. https://doi.org/10.1162 /003355303322552775.

Besedeš, T., Deck, C., Sarangi, S., \& Shor, M. (2012). Age effects and heuristics in decision making. Review of Economics and Statistics, 94(2), 580-595. https://doi.org/10.1162/REST_ a 00174 .

Bianchini, S., Bottazzi, G., \& Tamagni, F. (2017). What does (not) characterize persistent corporate high growth? Small Business Economics, 48(3), 633-656. https://doi. org/10.1007/s11187-016-9790-1.

Bloningen, B. A., \& Tomlin, K. (2001). Size and growth of Japanese plants in the United States. International Journal of Industrial Organization, 19, 931-952. https://doi. org/10.1016/S0167-7187(99)00055-7.

Bottazzi, G., \& Secchi, A. (2006). Explaining the distribution of firm growth rates. RAND Journal of Economics, 37(2), 235$256 \mathrm{https}: / /$ www.jstor.org/stable/25046240.

Bottazzi, G., Dosi, G., Lippi, M., Pammolli, F., \& Riccaboni, M. (2001). Innovation and corporate growth in the evolution of the drug industry. International Journal of Industrial Organization, 19, 1161-1187. https://doi.org/10.1016 /S0167-7187(01)00068-6.

Bravo-Biosca, A., Criscuolo, C., \& Menon, C. (2016). What drives the dynamics of business growth? Economic Policy, 31(88), 703-742. https://doi.org/10.1093/epolic/eiw013.

Brunello, G., Graziano, C., \& Parigi, B. (2001). Executive compensation and firm performance in Italy. International Journal of Industrial Organization, 19, 133-161. https://doi.org/10.1016/S0167-7187(99)00026-0.

Bruton, G., Filatotchev, D., Chahine, I. S., \& Wright, M. (2009). Governance, ownership structure, and performance of IPO firms: The impact of different types of private equity investors and institutional environments. Strategic Management Journal, 31, 491-509. https://doi.org/10.1002/smj.822.

Cabral, L. M. B., \& Mata, J. (2003). On the evolution of the firm size distribution: Facts and theory. American Economic Review, 93, 1075-1090. https://doi.org/10.1257 /000282803769206205.

Capasso, M., Treibich, T., \& Verspagen, B. (2015). The mediumterm effect of R\&D on firm growth. Small Business
Economics, 45(1), 39-62. https://doi.org/10.1007/s11187015-9640-6.

Chaigneau, P., \& Sahuguet, N. (2018). The effect of monitoring on CEO compensation in a matching equilibrium. Journal of Financial and Quantitative Analysis, 53(3), 1297-1339. https://doi.org/10.1017/S0022109017001065.

Child, J. (1974). Managerial and organizational factors associated with company performance part I. Journal of Management Studies, 11(3), 175-189. https://doi.org/10.1111/j.14676486.1974.tb00693.x.

Citci, S. H., \& Inci, E. (2016). Career concerns and Bayesian overconfidence of managers. International Journal of Industrial Organization, 46, 137-159. https://doi. org/10.1016/j.ijindorg.2016.04.005.

Coad, A. (2007). Testing the principle of 'growth of the fitter': The relationship between profits and firm growth. Structural Change and Economic Dynamics, 18, 370-386. https://doi. org/10.1016/j.strueco.2007.05.001.

Coad, A., \& Rao, R. (2008). Innovation and firm growth in hightech sectors: A quantile regression approach. Research Policy, 37, 633-648. https://doi.org/10.1016/j. respol.2008.01.003.

Colombo, M. G., \& Grilli, L. (2005). Founders' human capital and the growth of new technology-based firms: A competencebased view. Research Policy, 34(6), 795-816. https://doi. org/10.1016/j.respol.2005.03.010.

Colombo, M. G., \& Grilli, L. (2010). On growth drivers of hightech start-ups: Exploring the role of founders' human capital and venture capital. Journal of Business Venturing, 25(6), 610-626. https://doi.org/10.1016/j.jbusvent.2009.01.005.

Cooley, T. F., \& Quadrini, V. (2004). Financial markets and firm dynamics. American Economic Review, 91, 1286-1310. https://doi.org/10.1257/aer.91.5.1286.

Cosh, A., \& Hughes, A. (1997). Executive remuneration, executive dismissal and institutional shareholdings. International Journal of Industrial Organization, 15, 469-492. https://doi. org/10.1016/S0167-7187(96)01031-4.

Criscuolo, C., Gal, P., \& Menon, P. (2014). The dynamics of employment growth: New evidence from 18 countries. OECD Science, Technology and Industry Policy Papers, No.14, OECD Publishing, Paris, https://doi.org/10.1787 /5jz417hj6hg6-en.

Cronqvist, H., Makhija, A. K., \& Yonker, S. E. (2012). Behavioral consistency in corporate finance: CEO personal and corporate leverage. Journal of Financial Economics, 102, 20-40. https://doi.org/10.1016/j.jfineco.2011.08.005.

Danielson, M. G., \& Scott, J. A. (2007). A note on agency conflicts and the small firm investment decision. Journal of Small Business Management, 45(1), 157-175. https://doi. org/10.1111/j.1540-627X.2007.00205.x.

Das, S. (1995). Size, age and firm growth in an infant industry: The computer hardware industry in India. International Journal of Industrial Organization, 13, 111-126. https://doi.org/10.1016/0167-7187(94)00453-9.

Denis, D. D., Denis, D. K., \& Atulya, S. (1998). Agency problems, equity ownership and corporate diversification. Journal of Finance, 52(1), 135-160. https://doi.org/10.2307/2329559.

Donaldson, G., \& Lorsch, J. (1983). Decision Making at the Top. Basic Books.

Dosi, G., Marsili, O., Orsenigo, L., \& Salvatore, R. (1995). Learning, market selection and evolution of industrial 
structures. Small Business Economics, 7, 411-436 https://www.jstor.org/stable/40228774.

Dosi, G., Moschella, D., Pugliese, E., \& Tamagni, F. (2015). Productivity, market selection, and corporate growth: Comparative evidence across US and Europe. Small Business Economics, 45, 643-672. https://doi.org/10.1007 /s11187-015-9655-z.

El Shoubaki, A., Laguir, I., \& den Besten, M. (2020). Human capital and SME growth: The mediating role of reasons to start a business. Small Business Economics, 54, 1107-1121. https://doi.org/10.1007/s11187-018-0129-y.

Elia, S., Greve, P., Vallone, T., \& Castellani, D. (2021). The micro-foundations of industrial diversification through foreign acquisitions: the multifaceted role of $\mathrm{CEO}$ experience. Long Range Planning. https://doi.org/10.1016/j. lrp.2021.102104.

Ericson, R., \& Pakes, A. (1995). Markow-perfect industry dynamics: A framework for empirical work. Review of Economic Studies, 62, 53-82. https://doi.org/10.2307/2297841.

Esteve-Pérez, S., Pieri, F., \& Rodriguez, D. (2021). One swallow does not make a summer: Episodes and persistence in high growth. Small Business Economics. https://doi.org/10.1007 /s11187-020-00443-8.

Evans, D. S. (1987). Tests of alternative theories of firm growth. Journal of Political Economy, 95, 657-674. https://doi. org/10.1086/261480.

Faccio, M., Marchica, M.-T., \& Mura, R. (2016). CEO gender, corporate risk-taking, and the efficiency of capital allocation. Journal of Corporate Finance, 39, 193-209. https://doi. org/10.1016/j.jcorpfin.2016.02.008.

Falk, A., Becker, A., Dohmen, T., Enke, B., Huffman, D. B., \& Sunde, U. (2018). Global evidence on economic preferences. Quarterly Journal of Economics, 133(4), 1645-1692. https://oi.org/10.1093/qje/qjy013.

Fazzari, S. M., Hubbard, R. G., \& Petersen, B. C. (1988). Financing constraints and corporate investment. Brookings Papers on Economic Activity, 1, 141-195. https://doi. org/10.2307/2534426.

Foss, N. J., \& Pedersen, T. (2016). Microfoundations in strategy research. Strategic Management Journal, 37(13), E22-E34. https://doi.org/10.1002/smj.2362.

Foster, L., Haltiwanger, J., \& Syverson, C. (2016). The slow growth of new plants: Learning about demand. Economica, 83, 91-129. https://doi.org/10.1111/ecca.12172.

Gabaix, X., Landier, A., \& Sauvagnat, J. (2013). CEO pay and firm size: An update after the crisis. The Economic Journal, 124, F40-F59. https://doi.org/10.1111/ecoj.12084.

Geroski, P. (1999). The growth of firms in theory and practice. CEPR Discussion Paper n. 2092.

Geurts, K., \& Van Biesebroeck, J. (2016). Firm creation and postentry dynamics of de novo entrants. International Journal of Industrial Organization, 49, 59-104. https://doi.org/10.1016 /j.ijindorg.2016.08.002.

Gibrat, R. (1931). Les inégalités économiques. Librairie du Recueil Sirey.

Grazzi, M., \& Moschella, D. (2018). Small, young, and exporters: New evidence on the determinants of firm growth. Journal of Evolutionary Economics, 28(1), 125-152. https://doi. org/10.1007/s00191-017-0523-7.

Hall, B. H. (1987). The relationship between firm size and firm growth in the U.S. manufacturing sector. The Journal of
Industrial Economics, 35(4), 583-600. https://doi. org/10.2307/2098589.

Haltiwanger, J., Jarmin, R., \& Miranda, J. (2013). Who creates jobs? Small versus large versus young. The Review of Economics and Statistics, 95(2), 347-361. https://doi. org/10.1162/REST_a_00288.

Hambrick, D. C., \& Mason, P. A. (1984). Upper echelons: The organization as a reflection of its top managers. Academy of Management Review, 9, 193-206. https://doi.org/10.2307 1258434.

Harrison, R., Jaumandreu, J., Mairesse, J., \& Peters, B. (2014). Does innovation stimulate employment? A firm-level analysis using comparable micro-data from four European countries. International Journal of Industrial Organization, 35, 29-43. https://doi.org/10.1016/j.jindorg.2014.06.001.

Hart, P. E., \& Oulton, N. (1996). Growth and size of firms. The Economic Journal, 106(438), 1242-1252. https://doi. org/10.2307/2235518.

Heshmati, A. (2001). On the growth of micro and small firms: evidence from Sweden. Small Business Economics, 17, 213228. https://doi.org/10.1023/A:1011886128912.

Holmstrom, B. (1999). Managerial incentive problems: A dynamic perspective. Review of Economic Studies, 66, 169-182. https://doi.org/10.3386/w6875.

Hong, H., Kubik, J., \& Solomon, A. (2000). Security analysts' career concerns and herding of earning forecasts. RAND Journal of Economics, 31, 121-144. https://doi.org/10.2307 12601032.

Jensen, M. C. (1986). Agency costs of free cash flow, corporate finance, and takeovers. American Economic Review, 76(2), 323-329. https://doi.org/10.1017/cbo9780511609435.005.

Jensen, M. C., \& Meckling, W. H. (1976). Theory of the firm: Managerial behavior, agency costs and ownership structure. Journal of Financial Economics, 3(4), 305-360. https://doi. org/10.1016/0304-405X(76)90026-X.

Jovanovic, B. (1982). Selection and the evolution of industry. Econometrica, 50, 649-670. https://doi.org/10.2307 $/ 1912606$

Kato, T. (1997). Chief executive compensation and corporate groups in Japan: New evidence from micro data. International Journal of Industrial Organization, 15, 455467. https://doi.org/10.1016/S0167-7187(96)01030-2.

Koenker, R., \& Basset, G. S. (1978). Regression quantiles. Econometrica, 46, 33-50. https://doi.org/10.2307/1913643.

Kräkel, M., \& Müller, D. (2015). Merger efficiency and managerial incentives. International Journal of Industrial Organization, 41, 51-63. https://doi.org/10.1016/j. ijindorg.2015.05.004.

La Porta, R., Lopez-de-Silanes, F., Shleifer, A., \& Vishny, R. W. (1998). Law and Finance. Journal of Political Economy, 106(6), 1113-1155. https://doi.org/10.1086/250042.

Li, X., Low, A., \& Makhija, A. K. (2017). Career concerns and the busy life of the young CEO. Journal of Corporate Finance, 47, 88-109. https://doi.org/10.1016/j.jcorpfin.2017.09.006.

Lotti, F., Santarelli, E., \& Vivarelli, M. (2009). Defending Gibrat's law as a long-run regularity. Small Business Economics, 32, 31-44. https://doi.org/10.1007/s11187-007-9071-0.

Machado, J. A. F., Parente, P. M. D. C., \& Santos Silva, J. M. C. (2011). QREG2: Stata module to perform quantile regression with robust and clustered standard errors. In Statistical 
Software Components S457369. Boston College, Department of Economics.

Malmendier, U., \& Tate, G. (2005). CEO overconfidence and corporate investment. The Journal of Finance, 60, 26612700. https://doi.org/10.1111/j.1540-6261.2005.00813.x.

Malmendier, U., \& Tate, G. (2008). Who makes acquisitions? CEO overconfidence and the markets' reaction. Journal of Financial Economics, 89, 20-43. https://doi.org/10.1016/j. jineco.2007.07.002.

Marris, R. (1964). The Economic Theory of Managerial Capitalism. Free Press.

Moschella, D., Tamagni, F., \& Yu, X. (2019). Persistent highgrowth firms in China's manufacturing. Small Business Economics, 52, 573-594. https://doi.org/10.1007/s11187017-9973-4.

Nelson, R., \& Winter, S. (1982). An evolutionary theory of economic change. Harvard University Press.

Pieri, F. (2018). Vertical organization of production and firm growth. Industrial and Corporate Change, 27(1), 83-106. https://doi.org/10.1093/icc/dtx019.

Prendergast, C., \& Stole, L. (1996). Impetuous youngsters and jaded old-timers: Acquiring a reputation for learning. Journal of Political Economy, 104, 1105-1134. https://doi. org/10.1086/262055.

Scharfstein, D. S., \& Stein, J. C. (1990). Herd behavior and investment. American Economic Review, 80, 465-479.

Schloetzer, J. D., Tonello, M., \& Larkin, G. (2017). CEO Succession Practices. The Conference Board Research Report R-1634-17, The Conference Board Inc. Retrieved from: https://www.conference-board.org/retrievefile. cfm?filename=Panel-III\%2D \%2D-Schloetzer $\% 2 \mathrm{D} \% 2 \mathrm{D}$ Succession.pdf\&type $=$ subsite

Serfling, M. A. (2014). CEO age and the riskiness of corporate policies. Journal of Corporate Finance, 25, 251-273. https://doi.org/10.1016/j.jcorpfin.2013.12.013.

Serra, F., Pointon, J., \& Abdou, H. (2012). Factors influencing the propensity to export: A study of UK and Portuguese textile firms. International Business Review, 21, 210-224. https://doi.org/10.1016/j.ibusrev.2011.02.006.
Shleifer, A., \& Vishny, R. W. (1986). Large shareholders and corporate control. Journal of Political Economy, 94(3), 461-488.

Shleifer, A., \& Vishny, R. W. (1997). A survey on corporate governance. The Journal of Finance, 52(2), 737-783. https://doi.org/10.3386/w5554.

Szerb, L., \& Vörös, Z. (2019). The changing form of overconfidence and its effect on growth expectations at the early stages of startups. Small Business Economics. https://doi. org/10.1007/s11187-019-00297-9.

Thomsen, S., \& Pedersen, T. (2000). Ownership structure and economic performance in the largest European companies. Strategic Management Journal, 21, 689-705. https://doi. org/10.1002/(SICI)1097-0266(200006)21:6<689::AIDSMJ115>3.0.CO;2-Y.

Variyam, J. N., \& Kraybill, D. S. (1992). Empirical evidence on determinants of firm growth. Economics Letters, 38, 31-36. https://oi.org/10.1016/0165-1765(92)90157-T.

Williamson, O. (1964). The Economics of Discretionary Behavior: Managerial Objectives in the Theory of the Firm. Prentice-Hall.

Wooldridge, J. M. (2010). Econometric analysis of cross section and panel data. The MIT Press.

World Economic Forum. (2016). The 5 youngest CEOs of Fortune 500 companies. Retrieved from: https://www.weforum. org/agenda/2016/08/youngest-ceo-fortune-500-companies/

Yang, C. H., \& Tsou, M. W. (2020). Globalization and firm growth: Does ownership matter? Small Business Economics, 55, 1019-1037. https://doi.org/10.1007/s11187019-00170-9.

Yim, S. (2013). The acquisitiveness of youth: CEO age and acquisition behavior. Journal of Financial Economics, 103, 250-273. https://doi.org/10.1016/j.jfineco.2012.11.003.

Publisher's note Springer Nature remains neutral with regard to jurisdictional claims in published maps and institutional affiliations. 